\title{
Uganda: First Review Under the Policy Support Instrument and Modifications to Assessment Criteria-Staff Report; Press Release on the Executive Board Discussion; and Statement by the Executive Director for Uganda
}

In the context of the first review under the Policy Support Instrument and modifications to assessment criteria, the following documents have been released and are included in this package:

- $\quad$ the staff report for the First Review Under the Policy Support Instrument and Modifications to Assessment Criteria, prepared by a staff team of the IMF, following discussions that ended on May 8, 2007, with the officials of Uganda on economic developments and policies. Based on information available at the time of these discussions, the staff report was completed on May 31, 2007. The views expressed in the staff report are those of the staff team and do not necessarily reflect the views of the Executive Board of the IMF;

- $\quad$ a Press Release summarizing the views of the Executive Board as expressed during its June 15, 2007 discussion of the staff report that completed the review; and

- $\quad$ a statement by the Executive Director for Uganda.

The documents listed below have been or will be separately released.

Letter of Intent sent to the IMF by the authorities of Uganda*

Memorandum of Economic and Financial Policies by the authorities of Uganda*

Technical Memorandum of Understanding*

*Also included in Staff Report

The policy of publication of staff reports and other documents allows for the deletion of market-sensitive information.

To assist the IMF in evaluating the publication policy, reader comments are invited and may be sent by e-mail to publicationpolicy@imf.org.

Copies of this report are available to the public from

International Monetary Fund • Publication Services

$70019^{\text {th }}$ Street, N.W. • Washington, D.C. 20431

Telephone: (202) 623-7430 • Telefax: (202) 623-7201

E-mail: publications@imf.org • Internet: http://www.imf.org

Price: $\$ 18.00$ a copy

\section{International Monetary Fund Washington, D.C.}





\title{
INTERNATIONAL MONETARY FUND
}

\author{
UGANDA
First Review Under the Policy Support Instrument and Modifications to Assessment Criteria \\ Prepared by the African Department \\ (In consultation with other departments) \\ Approved by Robert Corker and Anthony R. Boote
}

May 31, 2007

- Main topics. This report recommends completion of the first review under the Policy Support Instrument (PSI). It also summarizes the policy implications of the proposed 2007/08 budget (July/June) and recent developments in the energy sector and the foreign exchange market.

- $\quad$ PSI. Uganda's second PSI was approved by the Executive Board on December 15, 2006. Program objectives include macro stability, debt sustainability, financial sector deepening and improved public sector financial management.

- $\quad$ Participants. The mission team met with Finance Minister Suruma, Bank of Uganda Governor Tumusiime Mutebile, other officials, and representatives of the private sector and the international community. The mission team comprised Messrs. Green (head, AFR), Gershenson, Saenz (both AFR), Espejo (PDR), and Jonas (FAD). Mr. Selassie, the Fund's resident representative in Kampala, participated in the discussions. Messrs. Gakunu and Ukpong joined policy discussions. 


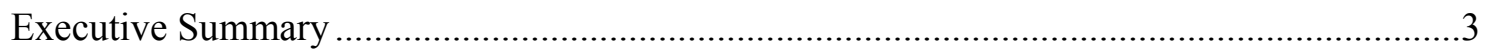

I. Strong Performance Under Unfavorable Circumstances................................................4

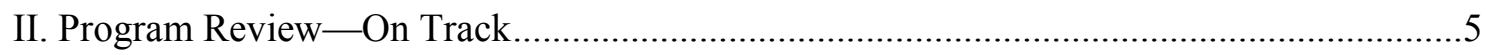

III. A Broadly Positive Outlook .......................................................................................

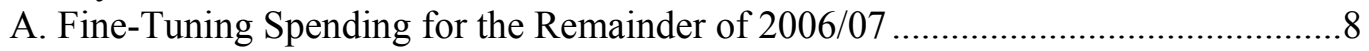

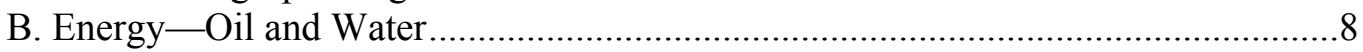

C. The 2007/08 Budget and the MTEF............................................................... 9

D. Monetary and Exchange Policies: Calibrating the Response to Inflows ................10

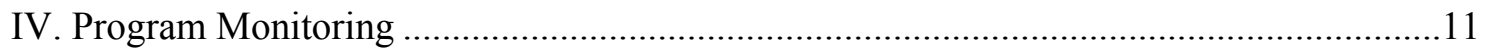

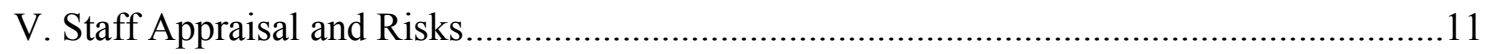

Tables

1. Quantitative Assessment Criteria and Indicative Targets for June-December 2007 ..16

2. Fiscal Operations of the Central Government, 2004/05-2008/09 .............................17

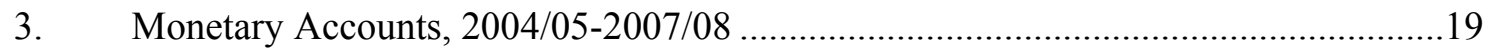

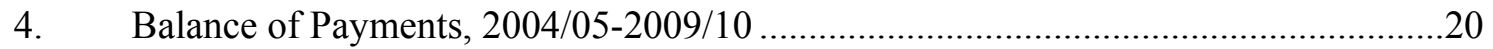

5. Medium-Term Macroeconomic Framework, 2005/06-2008/09 ..................................21

6. Quantitative Assessment Criteria and Indicative Targets

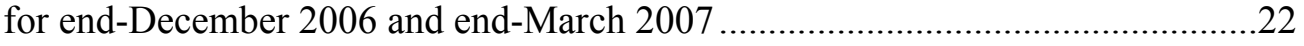

7. Structural Assessment Criteria and Benchmarks ....................................................23

8. Selected Banking Sector Information, December 2003-December 2006 ..................24

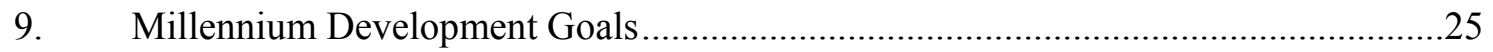

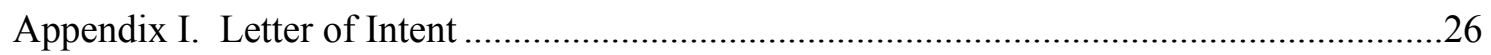

Attachment I. Memorandum of Economic and Financial Policies...........................27

Attachment II. Technical Memorandum of Understanding .......................................35 


\section{Executive Summary}

The staff recommends completion of the first review. All assessment criteria were met, macroeconomic performance has been good, and the outlook is positive. Temporary diesel generators and appropriate fiscal and monetary policy responses have helped to stabilize the electric power crisis and avert a major slowdown.

Uganda's medium-term expenditure framework (MTEF) aims at higher public savings based on spending restraint and a rising domestic revenue ratio. The 2007/08 budget will be guided by the MTEF, allowing for (i) additional investment in infrastructure, (ii) carryover energy crisis effects, (iii) provisions for avoiding new arrears, (iv) sufficient expenditure under the Poverty Action Fund (PAF), and (v) some revenue loss due to introduction of tax incentives. The tax-to-GDP ratio and the overall balance, excluding grants, would improve by about $1 / 2$ percent of GDP compared with the previous year, broadly in line with program objectives.

One-time increases in electricity tariffs and temporary sugar and diesel fuel shortages are behind the recent spike in inflation. A further monetary tightening was not warranted and could have jeopardized the welcome expansion in private sector credit. The program targets inflation of four percent by end-2007/08.

The shilling has appreciated against the dollar since late 2006, although it is not clear whether this is due to permanent or temporary factors. As is the current policy, the Bank of Uganda (BOU) will rely on a combination of foreign exchange sales and open market operations to sterilize liquidity. The BOU will monitor the situation closely to ascertain the exact nature of the inflows.

The main risks to the economic outlook are electricity and infrastructure bottlenecks. Delays in construction of the Bujagali dam would impose substantial costs on the government and businesses. Better and more extensive transport networks and expansion of the pool of long-term savings are also critical for sustainable economic growth. 


\section{Strong Performance Under Unfavorable Circumstances}

1. Uganda is weathering the electricity crisis reasonably well. The crisis erupted in early 2006 following the regional drought and led to the widespread blackouts. Blackouts, although still a problem, have eased following the installation of temporary diesel generators and a small boost to the hydroelectric power capacity from recent rains. The outlook for real growth is unchanged, between 6 and $6 \frac{1}{2}$ percent over the next few years.

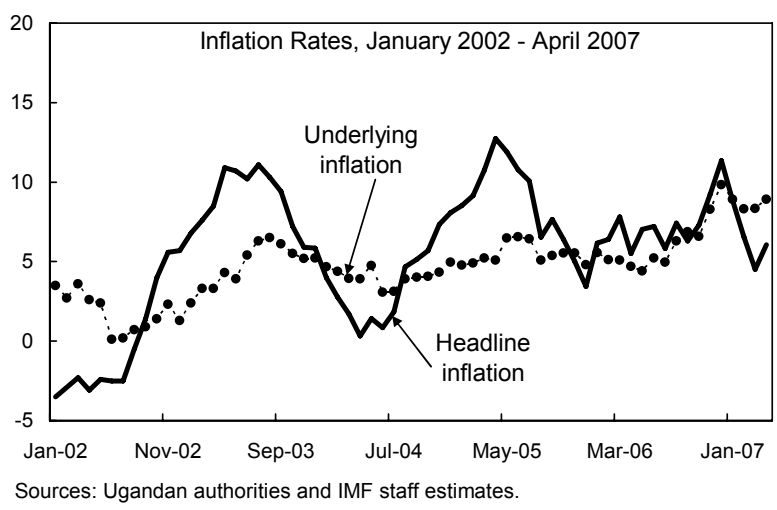

\section{A pick-up in underlying inflation in the first half of 2006/07 reflected}

temporary factors - the near-doubling of administered electricity tariffs and shocks to sugar production and diesel fuel delivery. The authorities and staff agreed that these were one-time events that affected relative prices and did not stem from an overly expansionary monetary stance. Underlying inflation is projected to fall below five percent in $2007 / 08$.

3. Uganda's poverty indicators are improving. The recently released household survey and Joint Staff Advisory Note (JSAN) show that robust economic growth and higher coffee prices in the past three years have benefited many Ugandans, as both the incidence of poverty and income inequality fell. ${ }^{1}$ Rapid population growth, however, moderated these gains. Sizeable regional differences in poverty remain, with the highest incidence in the north of the country, a region ravaged by a protracted civil conflict.

\footnotetext{
${ }^{1}$ Uganda Bureau of Statistics, Uganda National Household Survey 2005/06 (Kampala, December 2006), http://www.ubos.org.
} 

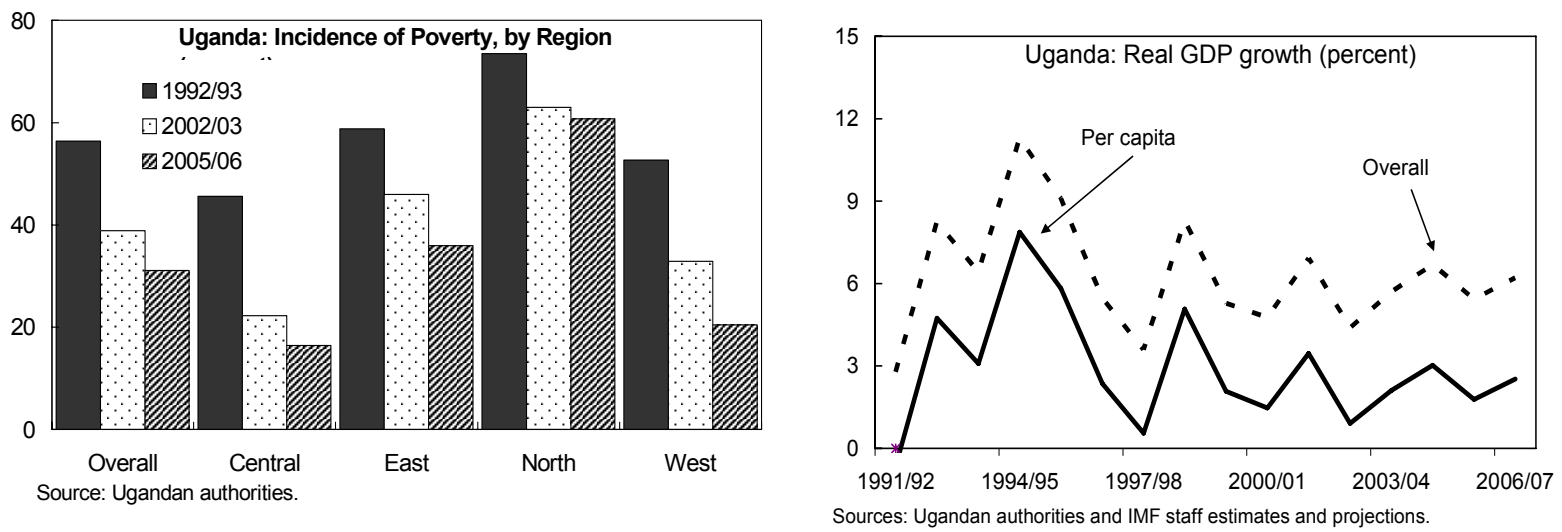

\section{Program Review-On Track}

\section{All assessment criteria were met through end-May (Tables 6 and 7).}

Disciplined fiscal performance, prudent monetary policy, and strong effort on the structural front underlied this outcome. An indicative target on poverty alleviation expenditure was missed by a small margin due to lags in expenditure processing. Domestic arrears repayment is on track to meet the 2006/07 budget allocation of $3 / 4$ percent of GDP, but the indicative target on the stock of arrears for end-June 2007 had to be revised upward, because new data showed accumulation of additional arrears in 2005/06.

\section{The real exchange rate has been appreciating, although its impact on} competitiveness is not yet clear. A pick-up in foreign exchange inflows, including portfolio inflows, has put upward pressure on the shilling-dollar exchange rate. At this point, it is not clear to what extent these inflows are temporary or relate to more fundamental factors, including demand for construction and recovery-related goods in neighboring countries, and improved prospects for oil production. To avoid instability in what is a relatively shallow foreign exchange market, the BOU intervened by suspending its regular foreign exchange sales for a limited period and relying more on open market operations to sterilize the inflows. The pick-up in domestic inflation also contributed to the real appreciation. 

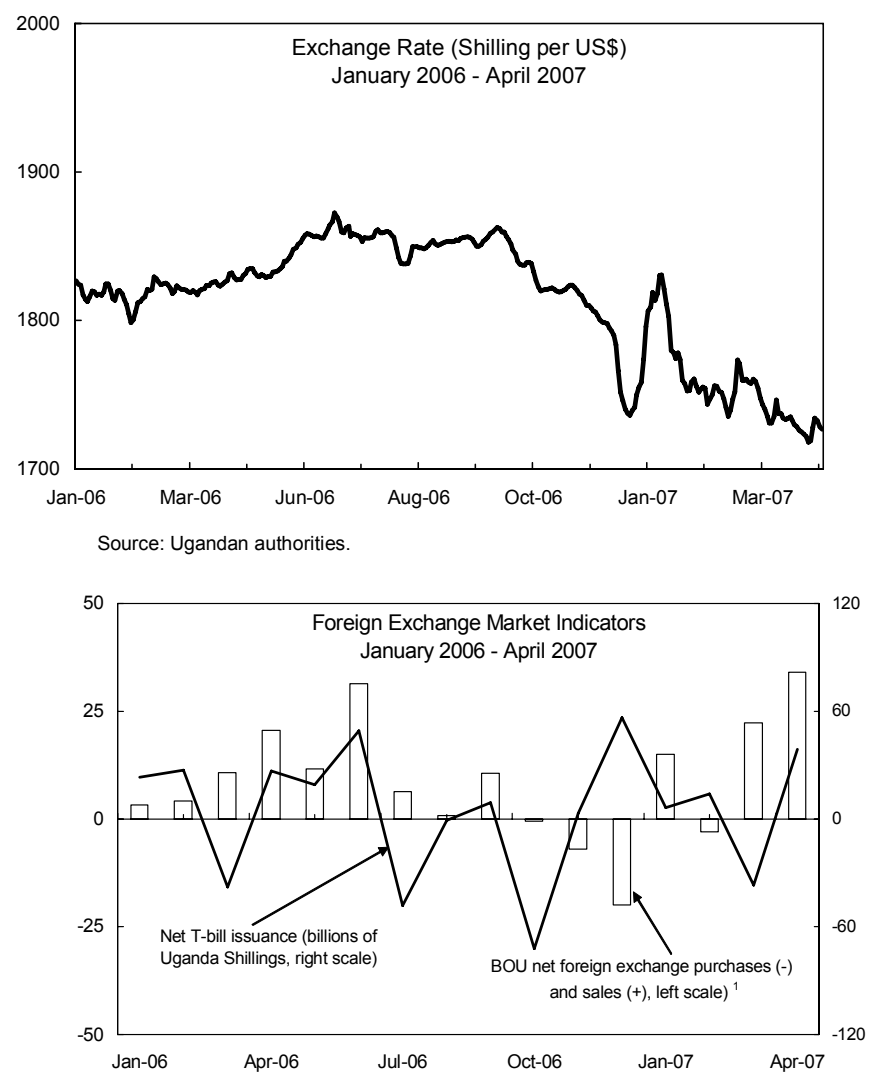

${ }^{1} \mathrm{BOU}$ net foreign exchange purchases and sales comprise monthly aggregations of daily data in millions of US dollars.

Source: Ugandan authorities.

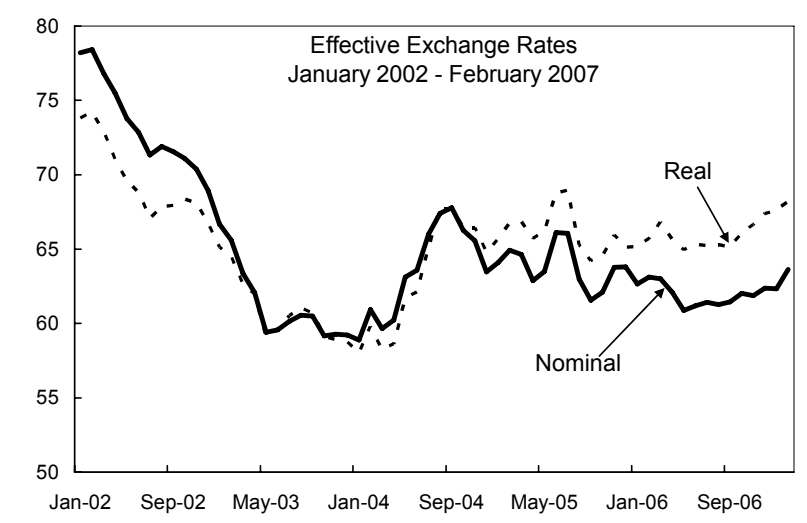

Sources: Ugandan authorities; IMF, Information Notice System. 
6. The robust economy and the government's negative borrowing requirement have been conducive to the development of the financial sector. Interest rates on treasury bills have remained broadly stable, and credit to the private sector has been growing strongly. Interest rate spreads, however, have remained high, underscoring the need for further reform.

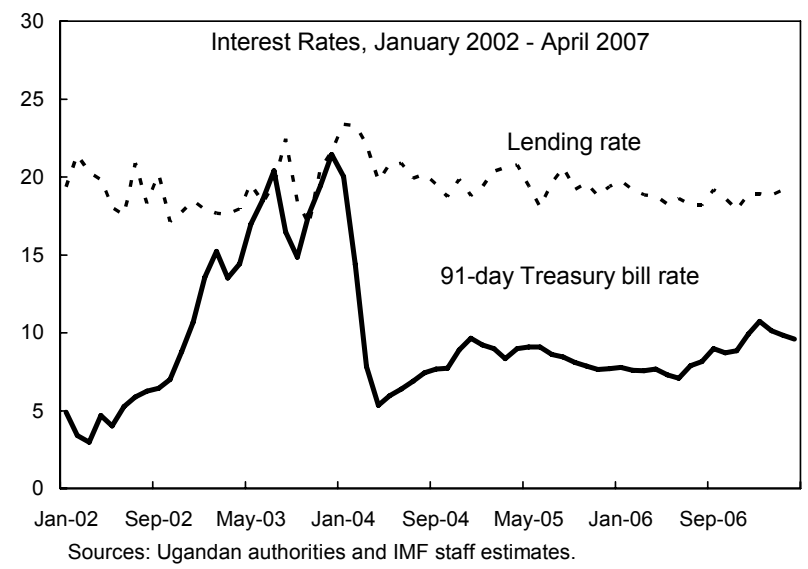

\section{A Broadly Positive Outlook}

7. Uganda's economic policies aim to reduce poverty by maintaining macro stability and addressing impediments to growth - in particular the infrastructure deficit. Thus, as set out in the PEAP and the PSI, the key policy challenges are:

- $\quad$ Continue gradual fiscal consolidation to lower dependence on donor funds;

- $\quad$ Maintain low inflation while minimizing sterilization costs and exchange rate pressures;

- Invest in health, education, and physical infrastructure; and

- $\quad$ Support private sector growth through second generation reforms.

8. Strong economic performance is expected to continue. Real GDP growth projections - above six percent for the coming years - and low inflation are based on implementation of the policy agenda listed above. The trade balance is projected to deteriorate due to imports for the Bujagali project and a decline in the terms of trade. Uganda's external position is sustainable and domestic debt is expected to decline. The government is tackling governance concerns, taking welcome action on a few high-profile cases, such as misappropriation of donor funds at the Ministry of Health. 
Uganda: Medium-Term Outlook

\begin{tabular}{lrrrr}
\hline & & & \\
& $2005 / 06$ & $2006 / 07$ & $2007 / 08$ & $2008 / 09$ \\
Proj. & Proj. & $\begin{array}{r}\text { Proj. } \\
\text { Prol }\end{array}$ \\
\hline Real GDP growth (percent) & 5.4 & 6.2 & 6.5 & 6.5 \\
Underlying average inflation (percent change) & 5.2 & 8.1 & 4.5 & 4.0 \\
Gross foreign exchange reserves (months of next year's imports) & 5.0 & 4.7 & 4.5 & 4.6 \\
Net donor inflows (percent of GDP) & 8.4 & 8.6 & 8.0 & 6.9 \\
Credit to the private sector (percent of GDP) & 8.6 & 9.0 & 10.2 & 10.3 \\
\hline
\end{tabular}

Sources: Ugandan authorities; and Fund staff estimates and projections.

\section{A. Fine-Tuning Spending for the Remainder of 2006/07}

\section{A fully-funded supplementary budget provided additional funding in several}

areas including for parliament (large one-off and smaller permanent allowances for members) and for local governments (to correct initial underbudgeting). A temporary bridge loan to the contractor is also planned so that the construction of Bujagali dam can start promptly (see below). The additional outlays are to be financed by reallocation from already-approved nonpriority spending, privatization proceeds, and higher-than-expected program support loans (Table 2), so that the fiscal program remains on track. Revenue collection in shilling terms also appears to be on track, but the anticipated rise in the revenue-to-GDP ratio is unlikely to materialize, reflecting the electricity crisis and perhaps overestimation of nominal GDP.

\section{B. Energy-Oil and Water}

\section{Full financing for Uganda's electricity sector follows the government's two- step approach to the current crisis.}

- In the near term, the high cost of temporary diesel generators is being met through a combination of tariff increases (nearly 100 percent in 2006) and government subsidies (about $1 / 2$ percent of GDP).

- In the medium term, the sector would be self-financing, with the subsidy ending when the Bujagali plant becomes operational sometime around 2011. Reflecting new, higher construction expenses, Bujagali generation costs are now estimated at around 10 U.S. cents per kilowatt-hour, from around 5 U.S. cents estimated two years ago. The authorities noted that there would still be scope for electricity charges to decline from current levels given that most higher-cost thermal generators would be phased out. The World Bank, which is providing a partial risk guarantee for the Bujagali project, supported this assessment. 
11. Financing arrangements for Bujagali are to be finalized around July 2007. Current plans cover the nearly US $\$ 800$ million cost through equity contributions by the government and a private consortium and loans to the consortium from development and commercial banks. The government has transferred money from its divestiture and general resources accounts into a special energy infrastructure fund at the Bank of Uganda. The fund will be used for (i) a temporary bridge loan to speed up Bujagali construction, (ii) escrow accounts related to Bujagali, and (iii) future projects. The bridge loan is to be repaid in $2007 / 08$.

\section{Test oil wells in western Uganda have recently shown that limited but} commercially viable production could begin by 2009. It could lower energy imports by US\$150 million a year and help alleviate the electricity crisis. The government has formed a task force to study the macroeconomic impact of oil and develop a national energy policy that would govern its use.

\section{The 2007/08 Budget and the MTEF}

13. The 2007/08 budget—to be presented to Parliament in mid-June-will be based on the government's strategy of increasing public savings through expenditure restraint and improved domestic revenue collection. To achieve the targeted increase in the revenue-to-GDP ratio by 0.5 percentage points, the government will continue with reforms at the Uganda Revenue Authority (URA), including further computerization, improved taxpayer registration and more frequent audits of tax compliance. The government will also submit to Parliament legislation to increase the local government revenue.

14. The 2007/08 budget framework identifies rural development, education, and infrastructure as priority areas. Thus, the framework highlights the importance of implementing road and electricity projects, rural development through enhanced extension, financial, and marketing services for farmers, and information technology. However, the limited share of discretionary resources in the budget, a near doubling (to 1.3 percent of GDP) of the allocation to clear arrears, and funds committed for universal secondary education curb new resources for the above areas and result in only modest increases in other priority areas such as health. Moreover, a drop in donor assistance and a shift from budget to project support will necessitate a small amount of domestic borrowing to close the fiscal gap. For medium-term sustainability, the government is continuing to look for higher efficiency in service delivery and is exploring pay reforms.

15. The authorities are planning to introduce tax incentives to encourage foreign investments and exports. The plan could introduce Export Processing Zones and possibly tax holidays in line with neighboring countries and incentives to export sectors such as horticulture. The staff urged the authorities to minimize the budgetary impact, the administrative burden on the URA, and any distortionary costs when finalizing the incentive scheme. 


\section{Debt management}

16. The authorities have prepared a comprehensive Debt Management Strategy to support their fiscal priorities. The draft strategy outlines the principles for external and domestic borrowing including borrowing only on concessional terms and only for budget support and essential infrastructure (electricity, transportation, and water) projects; and establishing strict limits on loan guarantees to the private sector. The strategy also (i) sets out the objective of repaying the remaining old domestic arrears during the next three years; and (ii) formulates policies to address the underlying causes of accumulation of new arrears (see MEFP, paras. 7-8). Measures to control arrears will be coordinated with Uganda's plan to strengthen financial management, FINMAP.

\section{The government intends to guarantee a US\$5.5 million nonconcessional loan} from the Japan Bank for International Cooperation (JBIC) to a local textile company. The project and its support from JBIC date back to around 2003; it was revitalized in late 2006. The staff initially questioned the need for a government guarantee for a private initiative, but was reassured that it would be exceptional and was intended to demonstrate Uganda's capacity to process its organic cotton and thus address a market information failure. Moreover, given the size of the loan, Uganda's external debt sustainability would not be compromised. Future support of this kind would be governed by the new debt strategy.

\section{Monetary and Exchange Policies: Calibrating the Response to Inflows}

18. The monetary program remains broadly unchanged. As the spike in inflation was driven by one-time factors, no monetary tightening is warranted. The program will continue to target base money and aim to bring underlying inflation to four percent by end-2007/08. The ceiling for base money also accommodates financial sector development through a decrease in velocity.

\section{The mix of instruments to} achieve the BOU's inflation objective will take into account the volume and nature of foreign exchange

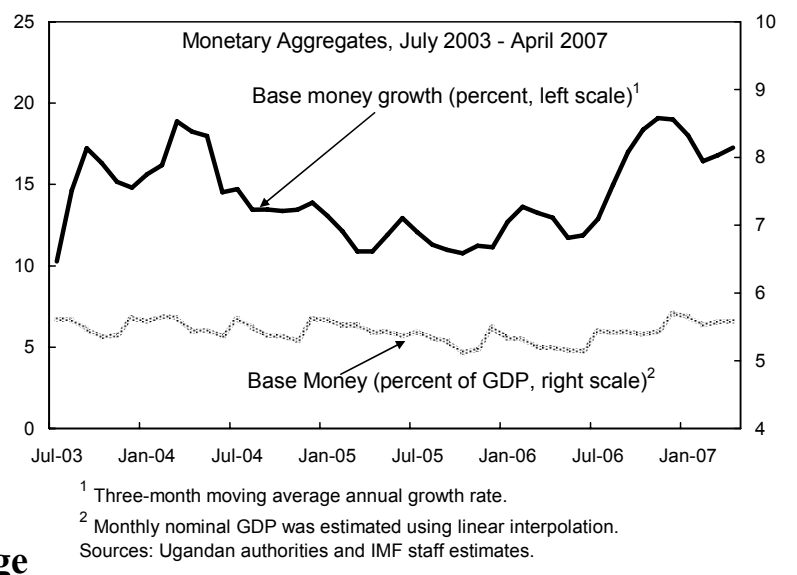
inflows. The volume of inflows permitting, the emphasis will be on foreign exchange sales. However, the BOU will rely on sales of government securities for monetary policy purposes when short-term fluctuations in inflows jeopardize Uganda's shallow foreign exchange market. To assess the nature of the inflows better, the BOU plans to tighten reporting requirements on treasury bill ownership and study invisible flows in the BOP. 


\section{Program Monitoring}

20. For monitoring performance under the program, quantitative assessment criteria, quantitative indicative targets, and structural assessment criteria and benchmarks have been set (MEFP, Tables 1 and 2). The end-June 2007 assessment criterion on net claims on government was modified to reflect a slightly lower domestic debt repayment. In addition, the end-June 2007 indicative target on arrears repayment was modified to take into account the newly-discovered stock of arrears accumulated in 2005/06. A former structural benchmark on establishing a new supervisory body for financial institutions was modified and made an assessment criterion, and an additional assessment criterion, on publication of Uganda's debt management strategy, was added. The standard provisions on the exchange system and trade issues that apply to the use of the Fund's financial resources will apply as continuous assessment criteria under the PSI. A recent voluntary safeguards assessment found notable progress in strengthening the BOU's safeguards framework (Appendix II).

\section{Staff Appraisal And Risks}

21. The staff recommends completion of the first review under the PSI. All assessment criteria were observed and prospects for growth and macroeconomic stability are good. The electricity crisis-the most pressing short-term challenge-is being addressed. Macroeconomic policies continue to be well-formulated and implemented.

\section{A sound Medium-Term Expenditure Framework (MTEF) underlies} Uganda's macroeconomic program. The pace of fiscal consolidation slowed in 2006/07, mainly because of the electricity crisis and its impact on the economy. For $2007 / 08$, prudent control over current, nonpoverty spending and efficiency gains in tax collections will be essential. The authorities will need to redouble their efforts to limit wasteful spending and supplementary budget reallocations in nonpriority areas and to continue implementation of URA modernization.

\section{The government has committed significant resources to repayment of} domestic arrears, but ultimately success will depend on fully funding statutory obligations and commitment to budget principles at all levels of government. To control further accumulation of arrears, FINMAP - the government's plan to strengthen public expenditure management - and other strategies should be put in place quickly.

24. The authorities are to be commended for their commitment to preserving debt sustainability, as expressed in the government's new debt management strategy. The principles governing the new borrowing are sound, and a centralized debt management unit should improve monitoring and control. The strict limits on loan guarantees to the private sector are welcome, and, if they had been already operational, would not have allowed the JBIC loan guarantee to proceed. The proposed exception, however, is a one-off event that should not be repeated. 
25. While inflation risks need to be monitored, a tightening of monetary policy appears unnecessary at this stage. One-time factors that have contributed to the recent spike in inflation are expected to subside, and a premature tightening could jeopardize the expansion in private sector credit. Nonetheless, the BOU should carefully screen the data for signs of underlying price pressures.

26. Likewise, the recent shilling appreciation requires monitoring, but fundamental shifts should not be resisted. In view of the shallowness of Uganda's foreign exchange market, the BOU's policy of market intervention to reduce volatility but not counter underlying movements is appropriate. Uganda's future competitiveness and ability to diversify its exports depend fundamentally on reducing the costs of production through investment in education and infrastructure, and financial market deepening.

27. The authorities should proceed cautiously on tax incentives, avoiding ad hoc decisions favoring specific market participants, and weighing the expected benefits against the available administrative capacity and lost tax revenue. Enhanced regional cooperation should be sought to avoid the risk of costly tax competition.

28. Further progress on governance is required. Sustained improvements in governance indicators could unlock substantial grant assistance available through the U.S. Millennium Challenge Account.

29. Main risks to program objectives would be failures to address key infrastructure bottlenecks and to deepen the financial sector. Delays in construction of the Bujagali dam would impose substantial medium-term costs on the government through continued subsidy of expensive thermal generation, as well as on businesses. Effective cost control will also be critical. Better and more extensive transport networks and expansion of the pool of long-term savings are also critical for sustainable economic growth. Uganda's comfortable reserves provide a buffer to deal with the short-term shocks. 
Table 1. Uganda: Selected Economic and Financial Indicators, 2004/05-2007/08 ${ }^{1}$

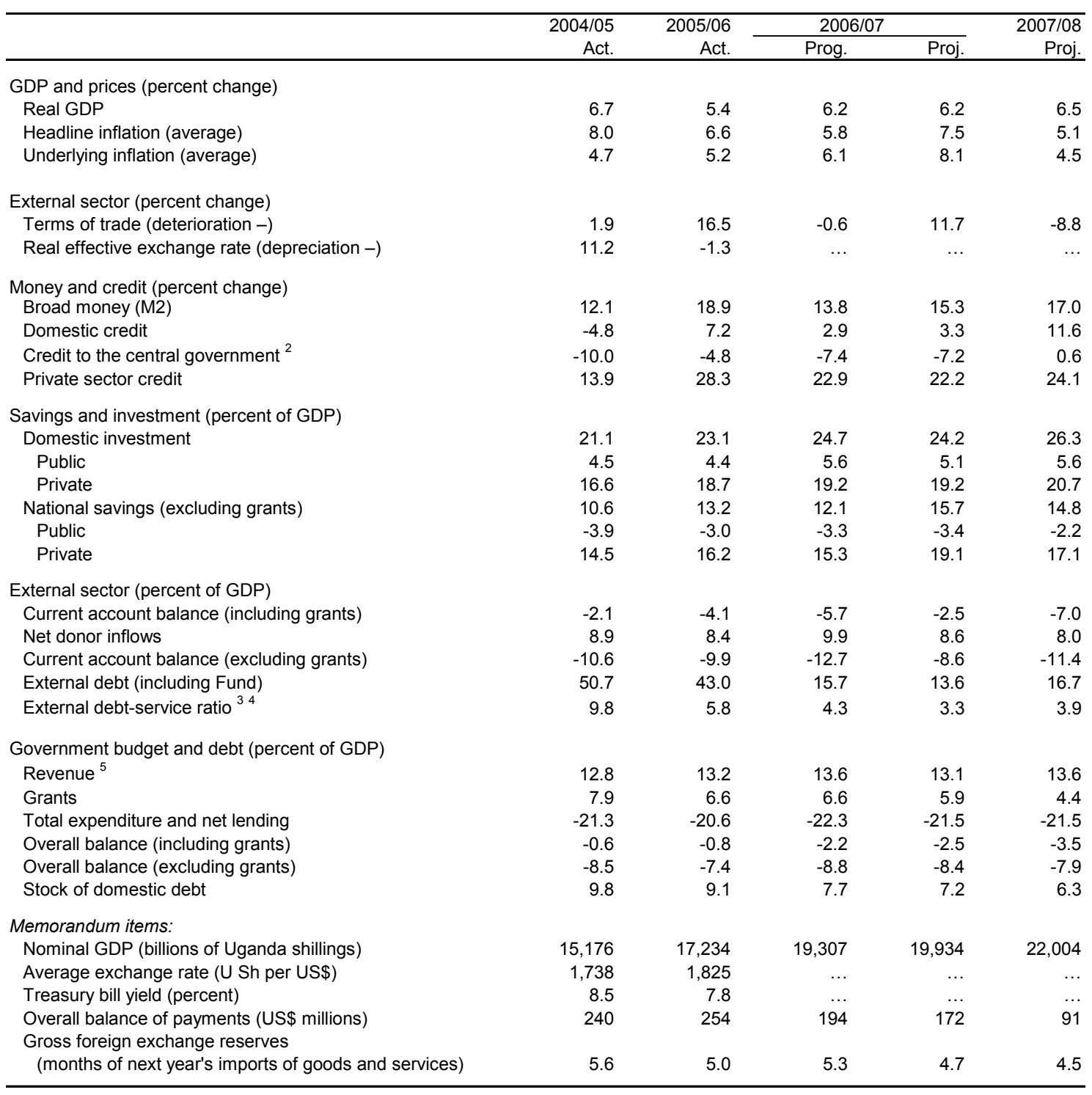

Sources: Ugandan authorities; and Fund staff estimates and projections.

${ }^{1}$ Fiscal year begins in July.

${ }^{2}$ Percent of M3 at start of the period.

${ }^{3}$ Percent of exports of goods and nonfactor services.

${ }^{4}$ Including Fund obligations; reflects actual debt service paid.

${ }^{5}$ Including unidentified revenue measures in 2007/08. 
Table 2. Uganda: Fiscal Operations of the Central Government, 2004/05-2008/09 ${ }^{1}$

\begin{tabular}{|c|c|c|c|c|c|c|}
\hline & $2004 / 05$ & $2005 / 06$ & $2006 /$ & & $2007 / 08$ & $2008 / 09$ \\
\hline & Actual & Actual & Prog. & Proj. & Proj. & Proj. \\
\hline & & Billions of $u$ & shillings) & & & \\
\hline Total revenue and grants & 3,146 & 3,403 & 3,894 & 3,776 & 3,954 & 4,366 \\
\hline Revenue & 1,948 & 2,267 & 2,619 & 2,602 & 2,993 & 3,454 \\
\hline Tax & 1,828 & 2,142 & 2,474 & 2,457 & 2,826 & 3,271 \\
\hline International trade taxes & 162 & 227 & 254 & 259 & 312 & 359 \\
\hline Income taxes & 560 & 653 & 800 & 750 & 869 & 1,007 \\
\hline Excises & 498 & 567 & 617 & 704 & 754 & 831 \\
\hline Value-added tax & 608 & 716 & 803 & 745 & 902 & 1,052 \\
\hline Additional revenue effort & 0 & 0 & 0 & -5 & -11 & 22 \\
\hline Nontax & 121 & 125 & 145 & 150 & 167 & 182 \\
\hline Grants & 1,198 & 1,136 & 1,274 & 1,174 & 962 & 912 \\
\hline Budget support & 811 & 713 & 718 & 722 & 500 & 479 \\
\hline Of which: MDRI (IMF) & & 229 & & & & \\
\hline Project grants & 387 & 424 & 557 & 452 & 462 & 432 \\
\hline Expenditures and net lending & 3,233 & 3,543 & 4,314 & 4,283 & 4,728 & 5,183 \\
\hline Current expenditures & 1,978 & 2,233 & 2,358 & 2,392 & 2,522 & 2,568 \\
\hline Wages and salaries & 774 & 867 & 975 & 976 & 1,009 & 1,046 \\
\hline Interest payments & 229 & 249 & 250 & 256 & 299 & 299 \\
\hline Other current & 975 & 1,117 & 1,133 & 1,160 & 1,213 & 1,223 \\
\hline Development expenditures & 1,187 & 1,249 & 1,734 & 1,617 & 1,944 & 2,063 \\
\hline Donor-supported projects & 700 & 730 & 1,040 & 885 & 1,105 & 1,177 \\
\hline Domestic-financed & 487 & 519 & 694 & 732 & 839 & 886 \\
\hline Of which: add'l energy crisis spending & $\ldots$ & $\ldots$ & 203 & 207 & 180 & 160 \\
\hline Net lending and investment & -8 & -29 & -2 & 57 & -138 & -7 \\
\hline Other spending $^{2}$ & 75 & 91 & 224 & 217 & 400 & 560 \\
\hline Overall balance & & & & & & \\
\hline Including grants & -86 & -139 & -421 & -507 & -774 & -818 \\
\hline Excluding grants & $-1,285$ & $-1,276$ & $-1,695$ & $-1,681$ & $-1,736$ & $-1,730$ \\
\hline Excl. grants and add'I energy spending & $\ldots$ & $\ldots$ & $-1,492$ & $-1,474$ & $-1,556$ & $-1,570$ \\
\hline Financing & 53 & 63 & 421 & 507 & 774 & 818 \\
\hline External financing (net) & 127 & 267 & 592 & 671 & 682 & 792 \\
\hline Disbursement & 285 & 466 & 770 & 828 & 842 & 944 \\
\hline Budget support & 11 & 76 & 287 & 395 & 198 & 200 \\
\hline Project loans & 274 & 390 & 483 & 433 & 643 & 744 \\
\hline Amortization (-) & -162 & -149 & -127 & -111 & -112 & -113 \\
\hline Exceptional financing & 4 & -50 & -51 & -45 & -48 & -41 \\
\hline Domestic financing (net) & -74 & -204 & -171 & -164 & 92 & 25 \\
\hline Bank financing & -260 & -135 & -242 & -235 & 22 & -73 \\
\hline Nonbank financing & 186 & -69 & 71 & 71 & 70 & 98 \\
\hline Errors and omissions/financing gap & 33 & 77 & 0 & 0 & 0 & 0 \\
\hline Memorandum items: & & & & & & \\
\hline MDRI spending & $\ldots$ & $\ldots$ & 56 & 56 & 86 & 86 \\
\hline MDRI debt relief from IDA & $\ldots$ & $\ldots$ & 4,772 & 4,560 & $\ldots$ & $\ldots$ \\
\hline MDRI debt relief from the AfDF & $\ldots$ & $\ldots$ & 981 & 938 & . & $\ldots$ \\
\hline
\end{tabular}


Table 2. Uganda: Fiscal Operations of the Central Government, 2004/05-2008/09 ${ }^{1}$ (concluded)

\begin{tabular}{|c|c|c|c|c|c|c|}
\hline & \multirow{2}{*}{$\begin{array}{r}\text { 2004/05 } \\
\text { Actual }\end{array}$} & \multirow{2}{*}{$\begin{array}{r}\text { 2005/06 } \\
\text { Actual }\end{array}$} & \multicolumn{2}{|c|}{$2006 / 07$} & \multirow{2}{*}{$\begin{array}{r}\text { 2007/08 } \\
\text { Proj. }\end{array}$} & \multirow{2}{*}{$\begin{array}{r}2008 / 09 \\
\text { Proj. }\end{array}$} \\
\hline & & & Prog. & Proj. & & \\
\hline & \multicolumn{4}{|c|}{ (Percent of GDP) } & & \\
\hline Total revenue and grants & 20.7 & 19.7 & 20.2 & 18.9 & 18.0 & 17.8 \\
\hline Revenue & 12.8 & 13.2 & 13.6 & 13.1 & 13.6 & 14.1 \\
\hline Tax & 12.0 & 12.4 & 12.8 & 12.3 & 12.8 & 13.4 \\
\hline International trade taxes & 1.1 & 1.3 & 1.3 & 1.3 & 1.4 & 1.5 \\
\hline Income taxes & 3.7 & 3.8 & 4.1 & 3.8 & 3.9 & 4.1 \\
\hline Excises & 3.3 & 3.3 & 3.2 & 3.5 & 3.4 & 3.4 \\
\hline Value-added tax & 4.0 & 4.2 & 4.2 & 3.7 & 4.1 & 4.3 \\
\hline Additional revenue effort & 0.0 & 0.0 & 0.0 & 0.0 & 0.0 & 0.1 \\
\hline Nontax & 0.8 & 0.7 & 0.8 & 0.8 & 0.8 & 0.7 \\
\hline Grants & 7.9 & 6.6 & 6.6 & 5.9 & 4.4 & 3.7 \\
\hline Budget support & 5.3 & 4.1 & 3.7 & 3.6 & 2.3 & 2.0 \\
\hline Of which: MDRI (IMF) & $\ldots$ & 1.3 & $\ldots$ & & & \\
\hline Project grants & 2.5 & 2.5 & 2.9 & 2.3 & 2.1 & 1.8 \\
\hline Expenditures and net lending & 21.3 & 20.6 & 22.3 & 21.5 & 21.5 & 21.2 \\
\hline Current expenditures & 13.0 & 13.0 & 12.2 & 12.0 & 11.5 & 10.5 \\
\hline Wages and salaries & 5.1 & 5.0 & 5.0 & 4.9 & 4.6 & 4.3 \\
\hline Interest payments & 1.5 & 1.4 & 1.3 & 1.3 & 1.4 & 1.2 \\
\hline Other current & 6.4 & 6.5 & 5.9 & 5.8 & 5.5 & 5.0 \\
\hline Development expenditures & 7.8 & 7.2 & 9.0 & 8.1 & 8.8 & 8.4 \\
\hline Donor-supported projects & 4.6 & 4.2 & 5.4 & 4.4 & 5.0 & 4.8 \\
\hline Domestic-financed & 3.2 & 3.0 & 3.6 & 3.7 & 3.8 & 3.6 \\
\hline Of which: add'l energy crisis spending & $\ldots$ & $\ldots$ & 1.1 & 1.0 & 0.8 & 0.7 \\
\hline Net lending and investment & -0.1 & -0.2 & 0.0 & 0.3 & -0.6 & 0.0 \\
\hline Other spending $^{2}$ & 0.5 & 0.5 & 1.2 & 1.1 & 1.8 & 2.3 \\
\hline \multicolumn{7}{|l|}{ Overall balance } \\
\hline Including grants & -0.6 & -0.8 & -2.2 & -2.5 & -3.5 & -3.3 \\
\hline Excluding grants & -8.5 & -7.4 & -8.8 & -8.4 & -7.9 & -7.1 \\
\hline Excl. grants and add'l energy spending & $\ldots$ & $\ldots$ & -7.7 & -7.4 & -7.1 & -6.4 \\
\hline Financing & 0.4 & 0.4 & 2.2 & 2.5 & 3.5 & 3.3 \\
\hline External financing (net) & 0.8 & 1.5 & 3.1 & 3.4 & 3.1 & 3.2 \\
\hline Disbursement & 1.9 & 2.7 & 4.0 & 4.2 & 3.8 & 3.9 \\
\hline Budget support & 0.1 & 0.4 & 1.5 & 2.0 & 0.9 & 0.8 \\
\hline Project loans & 1.8 & 2.3 & 2.5 & 2.2 & 2.9 & 3.0 \\
\hline Amortization (-) & -1.1 & -0.9 & -0.7 & -0.6 & -0.5 & -0.5 \\
\hline Exceptional financing & 0.0 & -0.3 & -0.3 & -0.2 & -0.2 & -0.2 \\
\hline Domestic financing (net) & -0.5 & -1.2 & -0.9 & -0.8 & 0.4 & 0.1 \\
\hline Bank financing & -1.7 & -0.8 & -1.3 & -1.2 & 0.1 & -0.3 \\
\hline Nonbank financing & 1.2 & -0.4 & 0.4 & 0.4 & 0.3 & 0.4 \\
\hline Errors and omissions/financing gap & 0.2 & 0.4 & 0.0 & 0.0 & 0.0 & 0.0 \\
\hline \multicolumn{7}{|l|}{ Memorandum item: } \\
\hline MDRI spending & $\ldots$ & $\ldots$ & 0.3 & 0.3 & 0.4 & 0.4 \\
\hline MDRI debt relief from IDA & $\ldots$ & $\ldots$ & 24.7 & 22.9 & $\ldots$ & $\ldots$ \\
\hline MDRI debt relief from the AfDF & $\ldots$ & $\ldots$ & 5.1 & 4.7 & $\ldots$ & 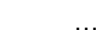 \\
\hline
\end{tabular}

Sources: Ugandan authorities; and Fund staff estimates and projections.

${ }^{1}$ Fiscal year begins in July.

${ }^{2}$ Includes contingency and arrears. 
Table 3. Uganda: Monetary Accounts, 2004/05-2007/08 ${ }^{1}$

(In billions of Uganda shillings; end of period, unless otherwise indicated)

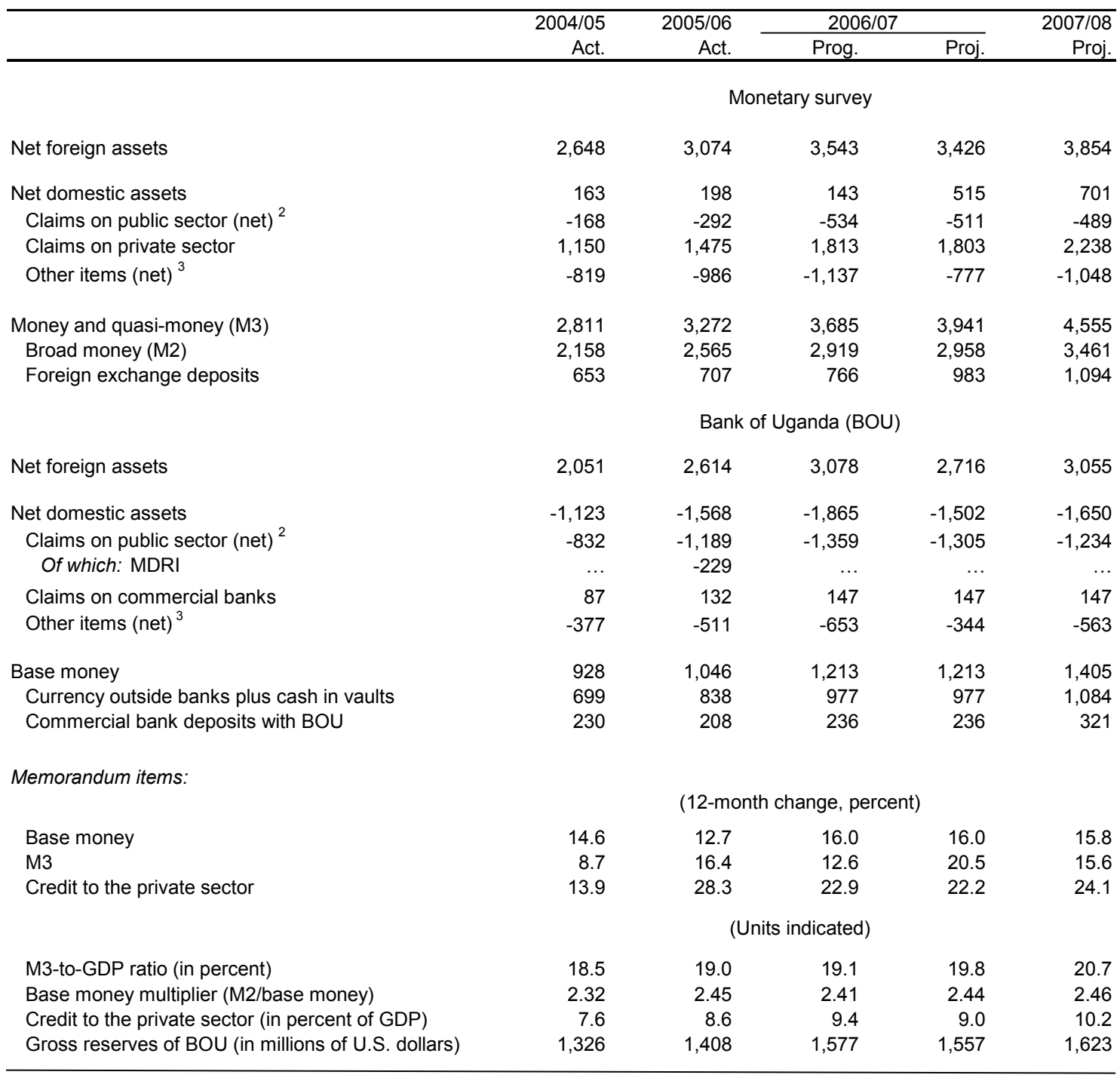

Sources: Ugandan authorities; and Fund staff estimates and projections.

${ }^{1}$ Fiscal year begins in July.

${ }^{2}$ The public sector includes the central government, the public enterprises, and the local government.

${ }^{3}$ Including valuation and the BOU's claims on private sector. 
Table 4. Uganda: Balance of Payments, 2004/05-2009/10 ${ }^{1}$ (Millions of dollars)

\begin{tabular}{|c|c|c|c|c|c|c|c|}
\hline & \multicolumn{2}{|c|}{ 2004/05 2005/06 } & \multicolumn{2}{|c|}{$2006 / 07$} & \multirow{2}{*}{$\begin{array}{r}2007 / 08 \\
\text { Proj. }\end{array}$} & \multirow{2}{*}{$\begin{array}{r}2008 / 09 \\
\text { Proj. }\end{array}$} & \multirow{2}{*}{$\begin{array}{r}2009 / 10 \\
\text { Proj. }\end{array}$} \\
\hline & Act. & Act. & Prog. & Proj. & & & \\
\hline Current account & -183 & -384 & -581 & -279 & -846 & $-1,039$ & -1116 \\
\hline Trade balance & -838 & $-1,102$ & $-1,278$ & $-1,197$ & $-1,631$ & $-1,801$ & -2065 \\
\hline Exports, f.o.b. & 786 & 890 & 1,029 & 1,180 & 1,270 & 1,360 & 1470 \\
\hline Of which: coffee & 145 & 173 & 206 & 227 & 231 & 242 & 256 \\
\hline Imports, f.o.b & $-1,624$ & $-1,991$ & $-2,307$ & $-2,377$ & $-2,900$ & $-3,162$ & -3535 \\
\hline Of which: oil & -158 & -290 & -358 & -381 & -428 & -471 & -506 \\
\hline Services (net) & -320 & -384 & -383 & -433 & -482 & -517 & -437 \\
\hline Income (net) & -168 & -135 & -133 & -119 & -156 & -203 & -184 \\
\hline Of which: interest on public debt & -38 & -36 & -18 & -22 & -30 & -31 & -33 \\
\hline Transfers & 1,143 & 1,237 & 1,213 & 1,470 & 1,423 & 1,482 & 1570 \\
\hline Private transfers & 401 & 687 & 497 & 798 & 879 & 966 & 1074 \\
\hline Of which: nongovernmental organizations & 248 & 530 & 333 & 515 & 566 & 623 & 685 \\
\hline Official transfers & 742 & 550 & 715 & 672 & 544 & 516 & 496 \\
\hline Of which: Budget support & 402 & 184 & 336 & 352 & 232 & 220 & 199 \\
\hline Project support & 223 & 232 & 295 & 252 & 255 & 237 & 237 \\
\hline HIPC grants & 81 & 81 & 45 & 51 & 45 & 43 & 44 \\
\hline Capital and financial account & 324 & 635 & 775 & 452 & 937 & 1,216 & 935 \\
\hline Capital account & 0 & 125 & 3,053 & 3,053 & 0 & 0 & 0 \\
\hline Of which: MDRI debt relief & 0 & 125 & 3,053 & 3,053 & 0 & 0 & 0 \\
\hline Financial account & 324 & 509 & $-2,278$ & $-2,601$ & 937 & 1,216 & 935 \\
\hline Foreign direct and portfolio investment & 235 & 257 & 312 & 322 & 431 & 614 & 700 \\
\hline Other investment & 89 & 252 & $-2,590$ & $-2,923$ & 506 & 603 & 235 \\
\hline Medium- and long-term & 69 & 184 & $-2,702$ & $-2,718$ & 602 & 564 & 509 \\
\hline \multicolumn{8}{|l|}{ Of which: } \\
\hline Public sector (net) & 71 & 174 & $-2,712$ & $-2,728$ & 479 & 457 & 309 \\
\hline Disbursements & 164 & 255 & 408 & 387 & 541 & 518 & 373 \\
\hline Project support & 158 & 214 & 256 & 242 & 356 & 409 & 263 \\
\hline Budget support & 6 & 42 & 152 & 220 & 110 & 110 & 110 \\
\hline Amortization due & -93 & -82 & $-3,120$ & $-3,115$ & -62 & -62 & -64 \\
\hline Private sector (net) & -2 & 10 & 10 & 10 & 123 & 108 & 201 \\
\hline Short-term & 20 & 68 & 112 & -205 & -96 & 38 & -274 \\
\hline Errors and omissions & 99 & 3 & 0 & 0 & 0 & 0 & 0 \\
\hline Overall balance & 240 & 254 & 194 & 172 & 91 & 177 & -180 \\
\hline Financing & -240 & -254 & -194 & -172 & -91 & -177 & 180 \\
\hline Central bank net reserves (increase $=-$ ) & -242 & -228 & -169 & -149 & -66 & -155 & 197 \\
\hline Of which: gross reserve change & -191 & -83 & -169 & -149 & -66 & -155 & 198 \\
\hline \multicolumn{8}{|l|}{ Memorandum items: } \\
\hline Coffee export volume (millions of $60-\mathrm{kg}$. bags) & 2.5 & 2.1 & 2.5 & 2.3 & 2.6 & 2.7 & 2.9 \\
\hline Coffee price (U.S. cents per kg.) & 96 & 137 & 139 & 162 & 150 & 150 & 147 \\
\hline Net donor support & 778 & 789 & 1,013 & 954 & 975 & 922 & 754 \\
\hline Of which: Budget support & 409 & 226 & 488 & 573 & 342 & 330 & 309 \\
\hline Project support & 380 & 446 & 551 & 494 & 611 & 646 & 500 \\
\hline Total HIPC debt relief & 91 & 78 & 110 & 46 & 42 & 39 & 42 \\
\hline
\end{tabular}

Sources: Ugandan authorities; and IMF staff estimates and projections.

${ }^{1}$ Fiscal year begins on July 1 . 
Table 5. Uganda: Medium-Term Macroeconomic Framework, 2005/06-2008/09 ${ }^{1}$

\begin{tabular}{lrrrr}
\hline & & & \\
& $2004 / 05$ & $2005 / 06$ & $2006 / 07$ & $2007 / 08$ \\
Proj. & $2008 / 09$ \\
Proj.
\end{tabular}

Sources: Ugandan authorities; and Fund staff estimates and projections.

${ }^{1}$ Fiscal year begins in July.

2 Including unidentified revenue measures in 2007/08 and 2008/09. 


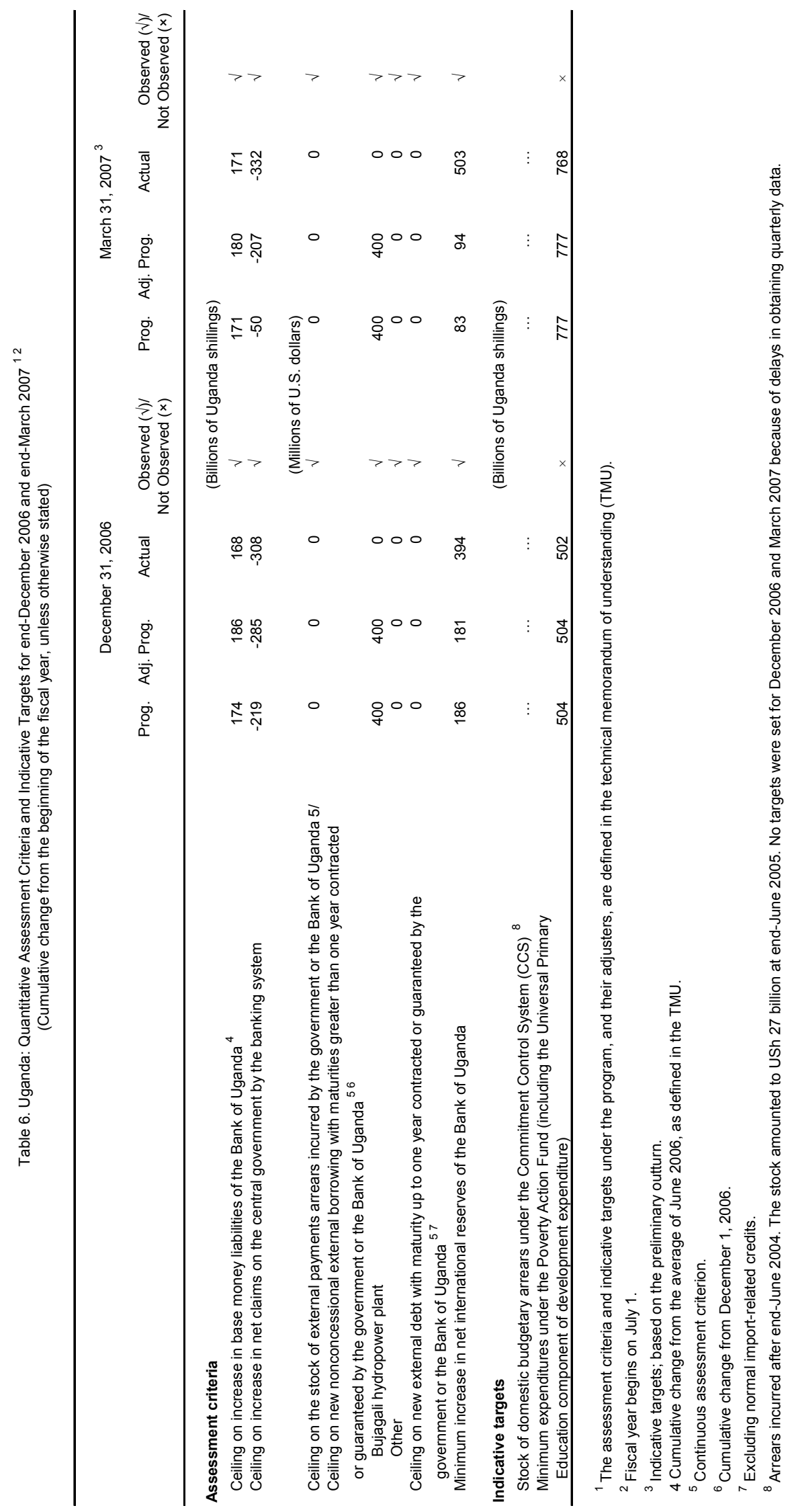


Table 7. Uganda: Structural Assessment Criteria and Benchmarks ${ }^{1}$

Policy Measure $\quad \begin{gathered}\text { Date of } \\ \text { Implementation }\end{gathered}$ Implementation Status

\section{Structural Assessment Criteria}

1. For $2007 / 08$ budget, allocate U Sh 300 billion for

End-June 2007

Revised $^{3}$

payments of group (A) verified domestic arrears. ${ }^{2}$

2. Verify the amount of pension payments due and prepare

End-May $2007 \quad$ On track

a review of pension payment and accounting systems, and

make recommendations for changes if necessary.

\section{Structural Benchmarks}

3. Introduce a system to verify overdue payments from all relevant government entities within 8 weeks of the end of

End-April $2007 \quad$ Completed each quarter.

4. Submit to Cabinet new insolvency legislation

5. Establish a new supervisory body for financial institutions not under the statutory supervision of the BOU. This will include private and public pension funds, insurance companies, and the Uganda Development Bank.

6. Introduce national identity card system
End-February $2008 \quad$ Revised $^{3}$

\footnotetext{
${ }^{1}$ Assessment criteria also apply on a continuous basis to the standard provisions on the exchange and trade issues that apply to programs supported by the Fund's financial resources.

${ }^{2}$ Group (A) arrears comprise the stock of pre-CCS, non-CCS, and CCS arrears incurred before end-June 2004.

${ }^{3}$ See Table 2 in the MEFP.
} 
Table 8. Uganda: Selected Banking Sector Information, December 2003-December 2006

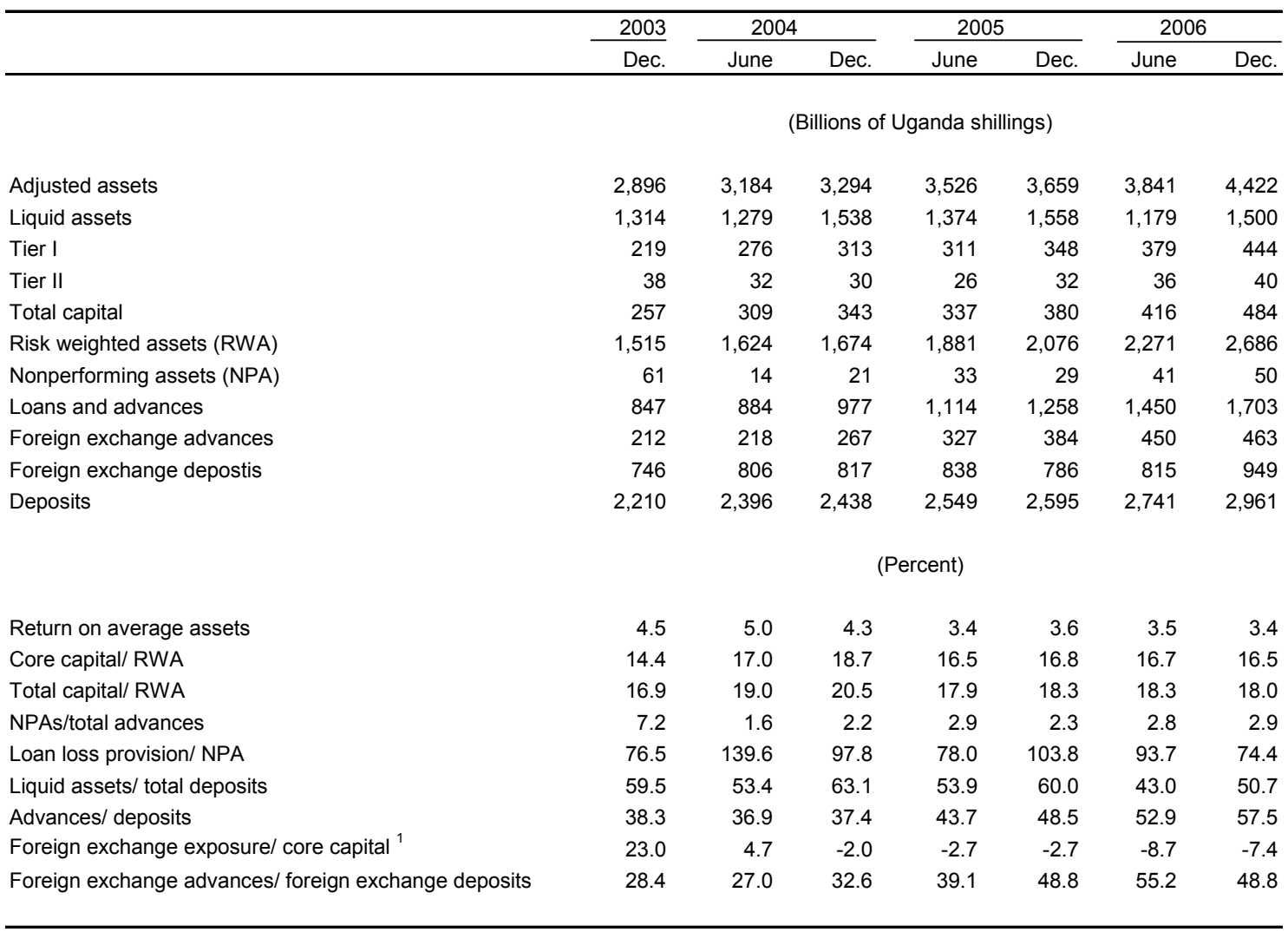

Source: Ugandan authorities.

${ }^{1}$ Foreign exchange exposure is calculated using the short-hand method. 
Table 9. Uganda: Millennium Development Goals

\begin{tabular}{|c|c|c|c|c|}
\hline & 1990 & 1995 & 2001 & 2004 \\
\hline Eradicate extreme poverty and hunger. & \multicolumn{4}{|c|}{2015 target $=$ halve $1990 \$ 1$ a day poverty and malnutrition rates } \\
\hline Percentage share of income or consumption held by poorest 20 percent & $\ldots$ & $\ldots$ & 5.9 & $\ldots$ \\
\hline Prevalence of child malnutrition (percent of children under 5) & 23.0 & 25.5 & 22.8 & $\ldots$ \\
\hline Population below minimum level of dietary energy consumption (percent) & 23.0 & 25.0 & 19.0 & $\ldots$ \\
\hline Achieve universal primary education. & \multicolumn{4}{|c|}{2015 target $=$ net enrollment to 100} \\
\hline Net primary enrollment ratio (percent of relevant age group) & $\ldots$ & 87.3 & $\ldots$ & 98.4 \\
\hline Youth literacy rate (percent of ages 15-24) & 70.1 & 74.7 & 79.4 & 76.6 \\
\hline Promote gender equality. & \multicolumn{4}{|c|}{2015 target $=$ education ratio to 100} \\
\hline Ratio of girls to boys in primary and secondary education (percent) & 76.8 & 81.0 & 95.0 & 97.1 \\
\hline Ratio of young literate females to males (percent of ages 15-24) & 75.8 & 80.4 & 85.0 & 86.1 \\
\hline Share of women employed in the nonagricultural sector (percent) & 43.2 & $\ldots$ & $\ldots$ & $\ldots$ \\
\hline Proportion of seats held by women in national parliament (percent) & 12.0 & 17.0 & 18.0 & 25.0 \\
\hline Reduce child mortality. & \multicolumn{4}{|c|}{2015 target $=$ reduce 1990 under -5 mortality by two-thirds } \\
\hline Under-5 mortality rate (per 1,000 ) & 160.0 & 156.0 & 145.0 & 137.8 \\
\hline Infant mortality rate (per 1,000 live births) & 93.0 & 92.0 & 85.0 & 80.2 \\
\hline Immunization, measles (percent of children under 12 months) & 52.0 & 57.0 & 61.0 & 91.0 \\
\hline Improve maternal health. & \multicolumn{4}{|c|}{2015 target $=$ reduce 1990 maternal mortality by three-fourths } \\
\hline Maternal mortality ratio (modeled estimate, per 100,000 live births) & $\ldots$ & $\ldots$ & 880.0 & $\ldots$ \\
\hline Births attended by skilled health staff (percent of total) & 38.3 & 37.8 & 39.0 & $\cdots$ \\
\hline Combat HIVIAIDS, malaria, and other diseases. & \multicolumn{4}{|c|}{2015 target $=$ halt, and begin to reverse, AIDS, etc. } \\
\hline Prevalence of HIV, female (percent of ages 15-24) & $\ldots$ & $\ldots$ & 4.6 & $\ldots$ \\
\hline Contraceptive prevalence rate (percent of women ages 15-49) & 4.9 & 14.8 & 22.8 & $\ldots$ \\
\hline Number of children orphaned by HIVIAIDS (thousands) & $\ldots$ & $\ldots$ & 880.0 & $\ldots$ \\
\hline Incidence of tuberculosis (per 100,000 people) & 161.1 & $\ldots$ & 324.0 & 401.6 \\
\hline Tuberculosis cases detected under DOTS (percent) ${ }^{1}$ & $\ldots$ & $\ldots$ & 44.4 & 43.0 \\
\hline Ensure environmental sustainability. & \multicolumn{4}{|c|}{2015 target $=$ various } \\
\hline Forest area (percent of total land area) & 25.9 & $\ldots$ & 21.3 & $18.4^{2}$ \\
\hline Nationally protected areas (percent of total land area) & $\ldots$ & 9.7 & 9.7 & $\ldots$ \\
\hline CO2 emissions (metric tons per capita) & 0.0 & 0.0 & 0.1 & $\ldots$ \\
\hline Access to an improved water source (percent of population) & 45.0 & $\ldots$ & 52.0 & $\ldots$ \\
\hline Access to improved sanitation (percent of population) & $\ldots$ & $\ldots$ & 79.0 & $\ldots$ \\
\hline Develop the Global Partnership for Development. & \multicolumn{4}{|c|}{2015 target $=$ various } \\
\hline Fixed line and mobile telephones (per 1,000 people) & 1.6 & 2.0 & 13.5 & 44.5 \\
\hline Personal computers (per 1,000 people) & $\ldots$ & 0.5 & 2.8 & 4.3 \\
\hline \multicolumn{5}{|l|}{ General indicators } \\
\hline Population (millions) & 17.8 & 20.9 & 25.1 & 27.8 \\
\hline Adult literacy rate (percent of people ages 15 and over) & 56.1 & $\ldots$ & $\ldots$ & 66.8 \\
\hline Total fertility rate (births per woman) & 7.2 & 6.9 & $\ldots$ & 7.1 \\
\hline Life expectancy at birth (years) & 45.7 & 43.1 & $\ldots$ & 48.9 \\
\hline
\end{tabular}

Source: World Development Indicators database, July 2006.

${ }^{1}$ Percentage of estimated new infectious tuberculosis cases detected under the directly observed treatment, short course case detection and treatment strategy.

2 Data for 2005. 


\title{
APPENDIX I-UGANDA: LETTER OF INTENT
}

Kampala, Uganda

May 17, 2007

\author{
Mr. Rodrigo de Rato \\ Managing Director \\ International Monetary Fund \\ Washington, D.C. 20431
}

Dear Mr. de Rato:

On behalf of the Government of Uganda, I would like to inform you of the progress we have made under our economic program backed by the International Monetary Fund's Policy Support Instrument (PSI) and transmit the attached Memorandum of Economic and Financial policies (MEFP), which sets out the objectives and policies that the Government intends to pursue in the short and medium term. The policies outlined in the MEFP are based on addressing Uganda's infrastructure needs in an environment of continued fiscal consolidation and implementation of the broader policy agenda as envisaged in the Poverty Eradication Action Plan.

All assessment criteria for the first review under the PSI were observed. The Government implemented vigorous measures to alleviate the electricity shortages, and macroeconomic performance and policies remained strong. Fiscal developments were broadly in line with the program objective of fiscal consolidation, and monetary policy targets were met.

The Government of Uganda believes that the policies set forth in the MEFP are adequate to achieve the objectives of our PSI program. Given our interest in macroeconomic stability, we stand ready to take additional measures as may be necessary to achieve needed objectives. Our PSI proposes assessment criteria for the performance target dates of end-June and endDecember 2007 for the second and third reviews, which are expected to be completed by endOctober 2007 and end-April 2008, respectively. We stand ready to work with the Fund and other development partners in the implementation of our program and will consult in advance should revisions be contemplated to the policies contained in the PSI.

The Government of Uganda authorizes the publication and distribution of this letter, its attachments, and all reports prepared by Fund staff regarding the current PSI review.

Sincerely yours,

$/ \mathrm{s} /$

Dr. Ezra Suruma

Minister of Finance, Planning, and Economic Development 


\section{APPENDIX I-ATTACHMENT I}

\section{Uganda: Memorandum of Economic and Financial Policies}

\section{UPDATE}

1. In this updated Memorandum of Economic and Financial Policies (MEFP), the Government of Uganda remains committed to sustained economic growth and poverty reduction. The strategy to achieve these goals is set out in the Poverty Eradication Action Plan (PEAP) and relies on prudent macroeconomic policies and structural changes. The Government and the International Monetary Fund (IMF) are cooperating on the economic program through a three-year Policy Support Instrument (PSI). This MEFP describes performance under the program through April 2007, specific policies and targets through the first half of 2007/08, and medium-term objectives.

\section{Performance Under the PSI}

2. All assessment criteria have been met. Fiscal performance for the first half of 2006/07 was in line with program projections, and, accordingly, the ceiling on net claims on government by the banking system was observed. Base money was within the program ceiling and the floor on the stock of net international reserves of the Bank of Uganda (BOU) was exceeded by a substantial margin. Poverty alleviation expenditure, an indicative target, was slightly below the program floor due to lags in expenditure processing.

\section{Objectives and Policies Looking Forward}

\section{A. Fiscal Policy}

\section{The outlook for the remainder of the fiscal year is in line with the Medium-} Term Expenditure Framework (MTEF) and program objectives set out in the initial MEFP. Spending on poverty reduction will be at intended levels. Government remains committed to meet the NCG target.

4. Our budget for $\mathbf{2 0 0 7 / 0 8}$ will be guided by our medium-term expenditure framework and our prudent approach to fiscal policy. Accordingly, we will aim to continue reducing the central government deficit (excluding grants) so that the private sector can lead economic growth and poverty reduction. However, our electric power situation will slow the pace of fiscal consolidation for the next several years. In addition, our 2007/08 budget will increase infrastructure spending and put emphasis on Government of Uganda counterpart funding for donor financed infrastructure projects. The policy of annually increasing tax collections by 0.5 percent of GDP remains in place but, as in 2006/07, implementation in the near term could be adversely affected by the high cost of electric power and by the temporary excise tax refunds on fuel used for large commercial generators. In addition, we will continue to subsidize electricity produced by 
thermal generators until the Bujagali dam is completed. Our quantitative targets for endDecember 2007 reflect these considerations and will be updated during the second PSI review to reflect the budget approved by Parliament. Parliament's final approval is expected by September 2007.

\section{The Ministry of Finance has developed a comprehensive debt management} strategy for Uganda. The strategy ties together the concept of fiscal sustainability and the goals of reducing dependency on donor flows and eliminating domestic arrears. The strategy calls for (i) borrowing only on concessional terms and only for budget support, agriculture and essential infrastructure (electricity, transportation, and water) projects;

(ii) streamlining debt management and finalizing regulations; and (iii) strict limits to the private sector on loan guarantees. Government will finalize the strategy paper and publish it.

6. The Government will make every effort to avoid the accumulation of new arrears to domestic suppliers. To this end, the Government will:

- $\quad$ Implement and enforce the arrears strategy that was recently adopted by Cabinet. The Ministry of Finance will also submit to Cabinet a paper restating the policy that requires that arrears accumulated since $2005 / 06$ be paid as soon as possible. The paper will propose mechanisms of settling these arrears in 2007/08;

- $\quad$ Maintain strict budget discipline;

- $\quad$ Roll out the IFMS further to all agencies; and

- $\quad$ Continue to submit to Cabinet quarterly CCS reports prepared by the Treasury Inspectorate, including details of ministries' arrears.

7. When finalizing our accounts for $\mathbf{2 0 0 5 / 0 6}$, we uncovered overdue obligations that were mainly related to utilities, supplier credits, and international subscriptions. These arrears will be cleared as quickly as possible, in line with our policy. To avoid new arrears in these areas, we will take the following steps:

- The Ministry of Foreign Affairs in conjunction with the Ministry of Finance, Planning and Economic Development will submit to Cabinet an updated list of international subscriptions and related host ministries to Cabinet for verification and approval. Further, the Ministry of Finance will advise all ministries that, starting with the 2007/08 financial year, subscription obligations will be met within their own budgets;

- The Ministry of Finance will republish in newspapers a reminder that Government will no longer honor supplier credits or other unofficial invoices for goods or services. Only local purchase orders (LPOs) from the IFMIS system will be paid; and 
- Government will continue working with its water and electricity suppliers to install prepaid meters over the next two years. Hospitals will be exempted.

8. The central government civilian pension payment system has been reviewed and found to be largely accurate. Nevertheless, plans to rollout the Integrated Payroll and Pension System (IPPS) in several ministries in time for the 2008/09 financial year will continue. During the review, we discovered that in recent years, pension obligations were higher than budget provisions. To avoid the problem of accumulating pension arrears in the future, the government will ensure that pensions in 2007/08 are paid on time.

9. The Government has reviewed investment incentives, including those granted to enterprises in Export Processing Zones (EPZs) as implemented in neighboring countries. Attracting investment to Uganda is a key part of the value addition strategy to bring more employment opportunities to Ugandans. We plan to present to Parliament a new investment policy that will be implemented during the 2007/08 financial year. The policy has been designed in line with the following principles: (i) avoid a significant erosion of the tax base so that our objective of increasing the tax-to-GDP ratio is achieved; (ii) avoid granting enterprise-based discretionary tax preferences;

(iii) implementation will take place as budgetary resources permit and taking into account the URA's capacity to monitor compliance. The plan is consistent with tax policies in our EAC partners and our intention to complete a code of conduct on investment incentives so that mutually damaging tax competition is avoided.

10. The Government has taken steps to pay tax on its own procurement. A special account has been set up in the BOU that will be used to make government tax payments to the URA. The new system has already begun to produce results, but it needs to be monitored carefully to ensure its effectiveness over time. Government will ensure that sufficient funds are allocated to this account and will address any new problems of government tax compliance as they arise.

11. The Government will strengthen mechanisms to ensure value-for-money in the implementation of public projects by strengthening the monitoring and evaluation functions, as well as service delivery. Past efforts in this area have proved difficult, and, consequently, the government will prepare a detailed plan to enhance the effectiveness of spending and service delivery in a few selected areas as demonstration of what can be achieved.

12. The Government is embarking on public sector pay reform. The Ministry of Public Service has produced a plan to revise public sector pay scales, to be implemented when resources permit. Higher pay for government scientists and researchers is also under review to retain them in Uganda. The Ministry of Public service is also reviewing public pensions, with due attention to the longer-term budgetary and financial market implications. As with pay reform, changes in the public pension system will depend on the availability of resources. 
13. The reform process in URA will continue and the URA will finalize its computerization program. In the medium term, the URA will further increase revenue collection, through improving taxpayer registration; centralization of data on custom, VAT, and income taxpayers and transactions; more frequent audits of tax compliance; identification of new taxpayers; and interconnectivity and sharing of information with countries in the region about incoming trade traffic.

14. The effective implementation of the fiscal decentralization strategy (FDS) is intended to improve government services. The Government is currently strengthening the public expenditure management systems at the subnational level, including IFMS implementation for local governments in accordance with the roll-out plan.

15. We are currently considering ways to strengthen local government finances. Abolition of the graduated tax, which was a key revenue source for local governments, has been compensated mainly by additional transfers from the central government. Some urban areas are collecting a local property tax to supplement central government transfers. The Government is looking at other tax options, but the scope for locally generated revenue in rural areas will remain limited until farmers are lifted out of subsistence agriculture.

\section{B. Monetary and Financial Sector Policies}

16. We remain committed to keeping annual average underlying inflation below five percent through the reserve money targeting framework. In 2006/07, this objective is unlikely to be achieved, largely because of (i) the necessary increases in electricity tariffs earlier in the year and (ii) a temporary jumps in sugar and diesel fuel prices. We see these developments as one-time supply shocks and not related to an inflationary pressure. In consequence, the BOU has maintained its targets for base money growth consistent with bringing inflation down below five percent by the end of the 2007/08 financial year.

\section{The BOU will continue to manage liquidity using an appropriate instrument} mix. Subject to the conditions in the foreign exchange market, BOU will continue to use sales of foreign exchange to sterilize donor inflows. However, the BOU will rely more heavily on open market operations for liquidity management if temporary appreciation pressures jeopardize the orderly operation of the foreign exchange market. At this stage, it is not clear whether the current appreciation pressure is due to permanent or temporary factors.

18. The BOU is pursuing the tools needed for a future inflation targeting framework. UBOS is expected to roll out a quarterly GDP index (by October 2007) and a new measure of underlying (core) inflation that would more accurately capture inflationary trends (in June 2007). The new CPI index will be monitored for a transition period of six months before it is published. The BOU will also start producing on a six- 
monthly basis a monetary conditions report that would relate current economic trends to monetary operations and the inflation target.

\section{To further promote the availability of financial services and lowering} borrowing costs, several initiatives are planned. The recently established credit reference bureau should help making loans more available. The effectiveness of the credit bureau will be enhanced with the expected introduction of the national identity cards. Further, the Government intends to implement the remaining key recommendations of the Financial Sector Assessment Program (FSAP) update, including:

- $\quad$ strengthening the corporate insolvency regime,

- Government submitted to cabinet in October 2006 a new insolvency legislation that gives creditors the right to commence bankruptcy procedures;

- $\quad$ strengthening institutional capacity of the commercial court and of Official Receiver; and

- $\quad$ addressing deficiencies in the land and company registries.

20. Improving the availability of financial services in rural areas is an important objective. Such services are being provided by member owned Savings and Credit Cooperatives (SACCOs), but we are concerned that they are not adequately supervised and lack basic accounting skills. To safeguard member deposits in these institutions, we are considering options to regulate SACCOs. In the meantime, we will ask Postbank Uganda (PBU) to assist by bolstering accounting capabilities of SACCOs. We intend to provide U Sh 8 billion in the 2007/08 budget for this effort. Otherwise, we, we expect that SACCOs will be self-supporting We will ensure that these actions are consistent with the existing regulatory and supervisory framework as contained in the Financial Institutions Act 2004 and its implementing regulations.

\section{Further development of the financial sector-including pensions-will make} long-term loans more available for housing and business expansion. Over time, longterm capital might also be used to finance infrastructure projects. Government has approved a plan to strengthen the Uganda Development Bank (UDB) so it can be operated along commercial principles, including providing loans that carry market-based interest rates. Government will not interfere with or direct activities of the UDB. We also plan to restructure the legal and regulatory framework for insurance and private pension companies, as these are the natural source of long-term credit. The new regulatory framework will cover insurance and pension companies, development banks (including UDB), the NSSF, and any financial institution not under the statutory supervision of the BOU. The new environment will ensure that pensions and other savings entrusted to these companies are prudently managed. We will submit the necessary policy paper to Cabinet by end-January 2008 . 


\section{Other Structural Reforms}

22. The Government attaches the utmost importance to addressing the shortage in power generation and will manage this with resources in the budget to defray the costs of the two already-installed temporary generators and stands ready to finance the third generator in the similar fashion, should donor financing be delayed further.

23. Our medium-term electricity strategy is anchored by hydropower projects, including Bujagali. The final agreements for Bujagali are expected to be signed by July 2007. The Government will provide a short-term US\$75 million bridge loan - to be repaid during the first half of 2007/08 - to the project's developer to jump-start the construction process. Our efforts to increase electricity supplies using temporary diesel generators is paying off, and power cuts have been reduced. We will install an additional $50 \mathrm{mw}$ of diesel generators and a 50mw heavy fuel plant in the first half of 2007/08. When these generators are in place, we will retire our most expensive diesel generators and also phase out the fuel excise tax exemption for large private generators.

\section{Prospects for commercial oil production have improved significantly in} recent months, and production could begin in the next several years. Government will put in place a national strategy to ensure that our new found oil will benefit all Ugandans. This strategy will include our commitment to manage these oil resources transparently and to use them consistently with macroeconomic stability. To help alleviate our severe electricity shortage, we intend to begin production, with output feeding a refinery that will mainly produce diesel and heavy fuel oil for electrical generation.

\section{The Government views inadequate infrastructure and low agricultural} productivity as major impediments to sustained economic growth. Reflecting this, agriculture, infrastructure development, including transportation, electricity, and water has been given priority in the 2007/08 budget and updated MTEF. In addition, our debt strategy limits new borrowing to these areas, after sources of grants have been exhausted. At the same time, we see implementation of infrastructure projects and maintenance of existing infrastructure as key constraints. We are looking at ways to improve procurement and management in these areas. 
Table 1. Uganda: Quantitative Assessment Criteria and Indicative Targets for June - December $2007^{1}$ (Cumulative change from the beginning of the fiscal year, unless otherwise stated) ${ }^{2}$

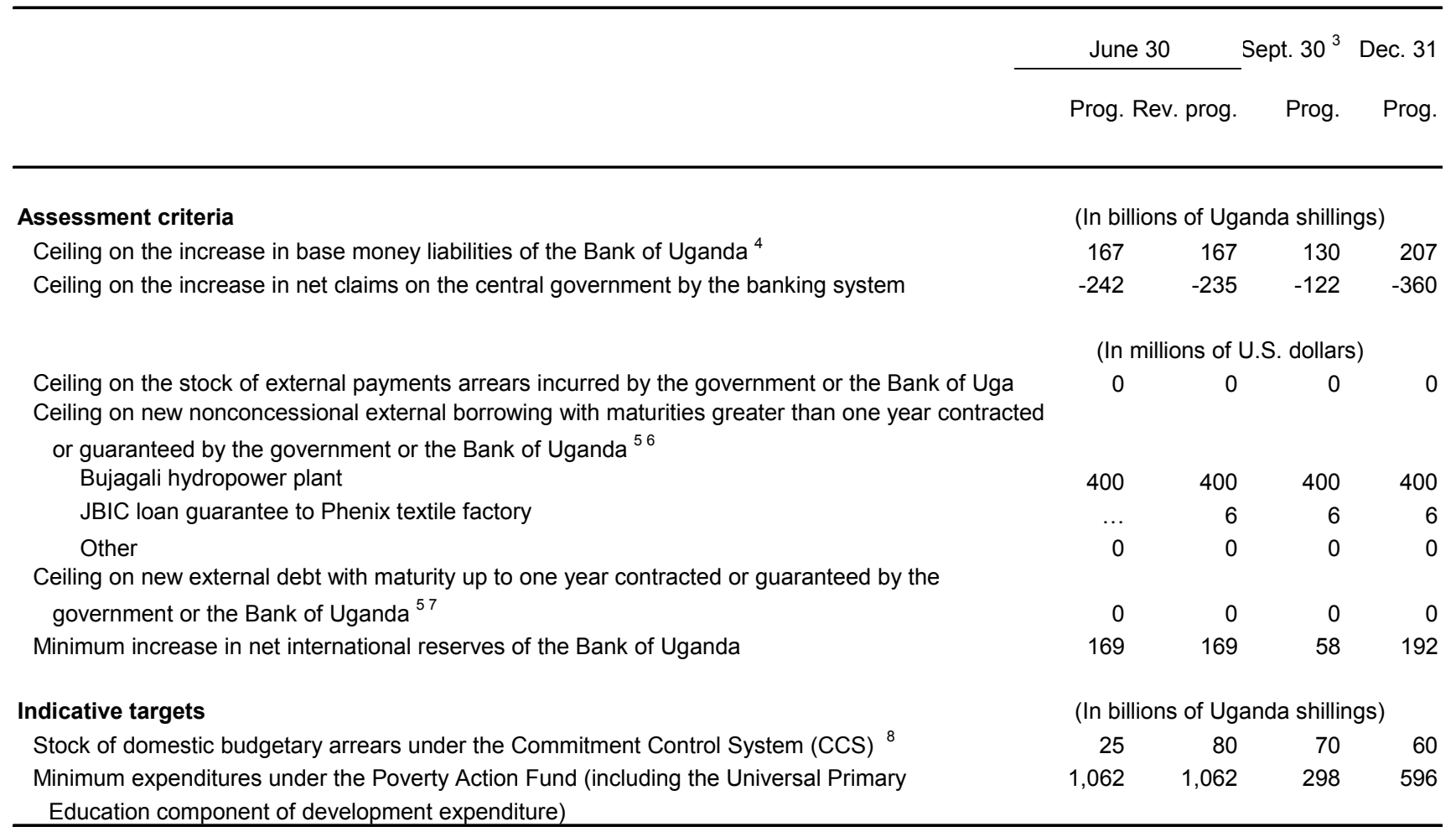

${ }^{1}$ The assessment criteria and indicative targets under the program, and their adjusters, are defined in the technical memorandum of understanding (TMU).

${ }^{2}$ Fiscal year begins on July 1.

${ }^{3}$ Indicative targets.

${ }^{4}$ For June 2007, cumulative changes from the average of June 2006; for September and December 2007, cumulative changes from the average of June 2007 , as defined in the TMU.

${ }^{5}$ Continuous performance criterion.

${ }^{6}$ Cumulative change from December 1, 2006.

${ }^{7}$ Excluding normal import-related credits.

${ }^{8}$ Arrears incurred after end-June 2004. The stock amounted to USh 27 billion at end-June 2005. 
Table 2. Uganda: Structural Assessment Criteria and Benchmarks ${ }^{1}$

\section{Structural Assessment Criteria}

1. For $2007 / 08$ budget, allocate U Sh 280 billion for payments of group (A) verified domestic arrears. ${ }^{2}$

2. Verify the amount of pension payments due and prepare a review of pension payment and accounting systems, and make recommendations for changes if necessary.

3. Finalize and publish the Government of Uganda Debt Strategy.

End-December 2007

4. Submit to cabinet a policy paper outlining the establishment of a new regulatory

End-January 2008 framework for financial institutions not under the statutory supervision of the BOU. These financial institutions will include private and public pension funds, insurance companies, and the Uganda Development Bank.

\section{Structural Benchmarks}

5. Introduce a system to verify overdue payments from all relevant government entities within 8 weeks of the end of each quarter.

End-April 2007 Completed

6. Submit to cabinet new insolvency legislation.

End-June 2007

7. Begin procurement process for the national identity card system.

End-February 2008

8. Roll out Integrated Payroll and Pension System in pilot ministries.

End-June 2008

\footnotetext{
${ }^{1}$ Assessment criteria will also apply on a continuous basis to the standard provisions on the exchange and trade issues that apply to programs supported by the Fund's financial resources.

${ }^{2}$ Group (A) arrears comprise the stock of pre-CCS, non-CCS, and CCS arrears incurred before end-June 2004.
} 


\section{APPENDIX I-ATTACHMENT II \\ Uganda: TeChNiCAL MeMorandum OF Understanding}

\section{A. Introduction}

1. This memorandum defines the targets described in the memorandum of economic and financial policies (MEFP) for the July 2006-June 2009 financial program supported by the IMF Policy Support Instrument (PSI), and sets forth the reporting requirements under the instrument.

\section{B. Base Money}

2. Base money is defined as the sum of currency issued by Bank of Uganda (BOU) and the commercial banks' deposits in the BOU. The commercial bank deposits include the statutory required reserves and excess reserves held at the BOU and are net of the deposits of closed banks at the BOU and Development Finance Funds (DFF) contributed by commercial banks held at the BOU. The base money limits - programmed on an endyear basis - will be cumulative changes from the daily average of June 2006 to the daily average of June 2007, and cumulative changes from the daily average of June 2007 to the daily average of September and December 2007.

\section{Net Claims on the Central Government by the Banking System}

3. Net claims on the central government (NCG) by the banking system is defined as the difference between the outstanding amount of bank credits to the central government and the central government's deposits with the banking system, excluding deposits in administered accounts and project accounts with the banking system, including the central bank. Credits comprise bank loans and advances to the government and holdings of government securities and promissory notes. Central government's deposits with the banking system include the full amount of IMF MDRI. NCG will be calculated based on data from balance sheets of the monetary authority and commercial banks as per the monetary survey. The quarterly limits on the change in NCG by the banking system will be cumulative beginning end-June in the previous fiscal year.

\section{Net International Reserves of the Bank of Uganda}

4. Net international reserves (NIR) of the BOU are defined for program monitoring purpose as reserve assets of the BOU net of short-term external liabilities of the BOU. Reserve assets are defined as external assets readily available to, and controlled by, the BOU and exclude pledged or otherwise encumbered external assets, including, but not limited to, assets used as collateral or guarantees for third-party liabilities. Short-term external liabilities are defined as liabilities to nonresidents, of original maturities less than one year, contracted by the BOU and include outstanding IMF purchases and loans. 
5. For program-monitoring purposes, reserve assets and short-term liabilities (excluding liabilities to the IMF) at the end of each test period will be calculated in U.S. dollars by converting reserve assets measured in Uganda shillings, as reported by the BOU, using the end-month Uganda shilling per U.S. dollar exchange rate. The U.S. dollar value of outstanding purchases and loans from the IMF will be calculated by converting the outstanding SDR amount reported by the Finance Department of the IMF using the U.S. dollar per SDR exchange rate at the end of each quarter.

\section{E. Ceiling on Domestic Budgetary Arrears of the Central Government}

6. The stock of domestic payment arrears under the Commitment Controls System (CCS) will be monitored on a quarterly basis. Domestic payments arrears under the CCS are defined as the sum of all bills that have been received by a central government spending unit or line ministry delivered in that quarter, and for which payment has not been made within 30 days under the recurrent expenditure budget (excluding court awards) or the development expenditure budget. For the purpose of program monitoring, the quarterly CCS reports, which will include arrears accumulated at IFMIS and nonIFMIS sites, prepared by the Internal Audit and Inspection Office will be used to monitor arrears. Arrears can be cleared in cash or through debt swaps.

7. The payments of pre-CCS, non-CCS, and CCS arrears accumulated up to endJune 2004 ("group A arrears") are covered by specific budget allocations for 2006/07 and $2007 / 08$. The program ceiling on the stock of CCS arrears only covers accumulation of arrears after end-June 2004 ("group B arrears"). According to the verified report prepared by the Internal Audit and Inspection Office, this stock of arrears is estimated at U Sh 27 billion as of June 2005 . As reported further in March 2007, approximately U Sh 65 billion of new arrears have been accumulated in 2005/06.

\section{F. Adjusters}

8. The NIR target is based on program assumptions regarding budget support, assistance provided under the Heavily Indebted Poor Countries (HIPC) Initiative and the Multilateral Debt Relief Initiative (MDRI), and external debt-service payments. The NCG target, in addition to being based on the aforementioned assumptions, is also based on assumptions regarding domestic nonbank financing of central government fiscal operations.

9. The Uganda shilling equivalent of budget support (grants and loans) plus HIPC Initiative assistance in the form of grants on a cumulative basis from July 1 of the fiscal year is presented under Schedule A. The ceiling on the cumulative increase in NCG will be adjusted downward (upward), and the floor on the cumulative increase in NIR of the BOU will be adjusted upward (downward) by the amount by which budget support, grants and loans, plus HIPC Initiative and MDRI assistance, exceeds (falls short of) the projected amounts. 


\begin{tabular}{|l|c|c|c|}
\hline \multicolumn{3}{|c|}{$\begin{array}{c}\text { Schedule A: Budget Support Plus Total HIPC Initiative Assistance } \\
\text { (Cumulative billions of Uganda shillings, beginning July 1 of the fiscal year) }\end{array}$} \\
\hline Quarter & June 30, 2007 & Sept. 30, 2007 & Dec. 31, 2007 \\
\hline $\begin{array}{l}\text { Budget support, including HIPC } \\
\text { Initiative grants }\end{array}$ & 1117 & 240 & 394 \\
\hline
\end{tabular}

10. The ceiling on the increases in NCG will be adjusted downward (upward) and the floor on the increase in NIR will be adjusted upward (downward) by the amount by which debt service due $e^{2}$ plus payments of external debt arrears less deferred payments (exceptional financing) falls short of (exceeds) the projections presented in Schedule B. Deferred payments are defined to be (i) all debt service rescheduled under the HIPC Initiative; and (ii) payments falling due to all non-HIPC Initiative creditors that are not currently being serviced by the authorities (that is, gross new arrears being incurred).

\begin{tabular}{|c|c|c|c|}
\hline \multicolumn{4}{|c|}{$\begin{array}{l}\text { Schedule B: Debt Service Due, Before HIPC Initiative Assistance } \\
\text { (Cumulative billions of Uganda shillings, beginning July } 1 \text { of the fiscal year) }\end{array}$} \\
\hline Quarter & June 30, 2007 & Sept. 30, 2007 & Dec. 31,2007 \\
\hline $\begin{array}{l}\text { Debt service due before } \\
\text { HIPC, excluding } \\
\text { exceptional financing }\end{array}$ & 194 & 77 & 133 \\
\hline
\end{tabular}

11. The ceiling on the increase in NCG will be adjusted downward (upward) by any excess (shortfall) in nonbank financing ${ }^{3}$ less payment of domestic group A arrears relative to the programmed cumulative amounts presented in Schedule C. For the purpose of this adjuster, payment of domestic group A arrears cannot exceed the programmed amount by more than U Sh 45.0 billion.

\footnotetext{
${ }^{2}$ Debt service due is defined as pre-HIPC Initiative debt service due, but from 2003/04 onwards, this excludes HIPC Initiative debt rescheduling.

${ }^{3}$ Comprising the check float and the change in government securities and government promissory notes held by the nonbank sector. The change in government securities held by the nonbank sector will be calculated from the data provided by the Central Depository System (CDS).
} 


\begin{tabular}{|l|l|c|c|}
\hline \multicolumn{3}{|c|}{$\begin{array}{l}\text { Schedule C: Nonbank Financing Minus Repayment of Domestic Arrears } \\
\text { (Cumulative billions of Uganda shillings, beginning July 1 of the fiscal year) }\end{array}$} \\
\hline Quarter & June 30, 2007 & Sept. 30, 2007 & Dec. 31, 2007 \\
\hline $\begin{array}{l}\text { (A) Nonbank } \\
\text { financing }\end{array}$ & 71 & -38 & 25 \\
\hline $\begin{array}{l}\text { (B) Domestic arrears } \\
\text { repayment }\end{array}$ & 149 & 19 & 130 \\
\hline \begin{tabular}{l} 
(C) Total=(A)-(B) \\
\hline
\end{tabular} & -78 & -57 & -104 \\
\hline
\end{tabular}

12. The base money ceiling will be adjusted upward up to a maximum of U Sh 30 billion in June, September, and December 2007 if the average amount of currency issued by the BOU exceeds those projected in Schedule D. This currency adjuster was increased from U Sh 15 billion previously to allow the BOU more flexibility in an uncertain monetary environment.

\begin{tabular}{|l|c|c|c|}
\hline \multicolumn{4}{|c|}{ Schedule D: Currency Issued by the BOU } \\
(Cumulative billions of Uganda shillings, beginning July 1 of the fiscal year) \\
\hline Quarter & June 30, 2007 & Sept. 30, 2007 & Dec. 31, 2007 \\
\hline $\begin{array}{l}\text { Currency } \\
\text { issued by BOU }\end{array}$ & 139 & 41 & 145 \\
\hline
\end{tabular}

\section{G. External Borrowing Contracted or Guaranteed by the Central Government, Statutory Bodies, or the Bank of Uganda, and Arrears}

13. The assessment criterion on short-term debt refers to contracting or guaranteeing external debt with original maturity of one year or less by the government or the Bank of Uganda. Excluded from this assessment criterion are normal import-related credits. The definition of "debt" is set out in paragraph 17.

14. The program includes a ceiling on new nonconcessional borrowing with maturities greater than one year contracted or guaranteed by the government, statutory bodies, or the BOU. ${ }^{4}$ Nonconcessional borrowing is defined as loans with a grant element of less than 35 percent, calculated using average commercial interest rates references

\footnotetext{
${ }^{4}$ Contraction is defined as approval by a resolution of Parliament as required in Section 20(3) of the Public Finance and Accountability Act, 2003
} 
(CIRRs) published by the Organization for Economic Cooperation and Development (OECD). In assessing the level of concessionality, the 10-year average CIRRs should be used to discount loans with maturities of at least 15 years, while the 6-month average CIRRs should be used for loans with shorter maturities. To both the 10-year and 6-month averages, the following margins for differing payment periods should be added: 0.75 percent for repayment periods of less than 15 years; 1 percent for 15-19 years; 1.15 percent for 20-25 years; and 1.25 percent for 30 years or more. The ceiling on nonconcessional external borrowing or guarantees is to be observed on a continuous basis. The coverage of borrowing includes financial leases and other instruments giving rise to external liabilities, contingent or otherwise, on nonconcessional terms. Excluded from the limits are changes in indebtedness resulting from refinancing credits and rescheduling operations, and credits extended by the IMF. For the purposes of the program, arrangements to pay over time obligations arising from judicial awards to external creditors that have not complied with the HIPC Initiative do not constitute nonconcessional external borrowing. For the purposes of the program, the Bujagali project is defined as the hydroelectric dam and related equipment located at the dam site.

15. The definition of debt, for the purposes of the limit, is set out in point 9 of the Guidelines on Performance Criteria with Respect to External Debt (Executive Board's Decision No. 12274-(00/85), August 24, 2000). It not only applies to the debt as defined in Point 9 of the Executive Board decision, but also to commitments contracted or guaranteed for which value has not been received. The definition of debt set forth in No. 9 of the Guidelines on Performance Criteria with Respect to External Debt in Fund Arrangements reads as follows:

(a) For the purpose of this guideline, the term "debt" will be understood to mean a current, i.e., not contingent, liability, created under a contractual arrangement through the provision of value in the form of assets (including currency) or services, and which requires the obligor to make one or more payments in the form of assets (including currency) or services, at some future point(s) in time; these payments will discharge the principal and/or interest liabilities incurred under the contract. Debts can take a number of forms, the primary ones being as follows: (i) loans, i.e., advances of money to the obligor by the lender made on the basis of an undertaking that the obligor will repay the funds in the future (including deposits, bonds, debentures, commercial loans and buyers' credits) and temporary exchanges of assets that are equivalent to fully collateralized loans under which the obligor is required to repay the funds, and usually pay interest, by repurchasing the collateral from the buyer in the future (such as repurchase agreements and official swap arrangements); (ii) suppliers' credits, i.e., contracts where the supplier permits the obligor to defer payments until some time after the date on which the goods are delivered or services are provided; and (iii) leases, i.e., arrangements under which property is provided which the lessee has 
the right to use for one or more specified period(s) of time that are usually shorter than the total expected service life of the property, while the lesser retains the title to the property. For the purpose of the guideline, the debt is the present value (at the inception of the lease) of all lease payments expected to be made during the period of the agreement excluding those payments that cover the operation, repair, or maintenance of the property. (b) Under the definition of debt set out in point 9(a) above, arrears, penalties, and judicially awarded damages arising from the failure to make payment under a contractual obligation that constitutes debt. Failure to make payment on an obligation that is not considered debt under this definition (e.g., payment on delivery) will not give rise to debt.

16. The ceiling on the accumulation of new external payments arrears is zero. This limit, which is to be observed on a continuous basis, applies to the change in the stock of overdue payments on debt contracted or guaranteed by the government, the BOU, and statutory bodies ${ }^{5}$ from their level at end-June 2006. It comprises those external arrears reported by the Trade and External Debt Department of the BOU, the Macro Department of the Ministry of Finance that cannot be rescheduled because they were disbursed after the Paris Club cutoff date.

\section{H. Monitoring and Reporting Requirements}

17. The authorities will inform the IMF staff in writing at least ten business days (excluding legal holidays in Uganda or in the United States) prior to making any changes in economic and financial policies that could affect the outcome of the financial program. Such policies include but are not limited to customs and tax laws (including tax rates, exemptions, allowances, and thresholds), wage policy, and financial support to public and private enterprises. The authorities will similarly inform the IMF staff of any nonconcessional external debt contracted or guaranteed by the government, the BOU, or any statutory bodies, and any accumulation of new external payments arrears on the debt contracted or guaranteed by these entities. The authorities will furnish an official communication to the IMF describing program performance of quantitative and structural assessment criteria and benchmarks within 8 weeks of a test date. The authorities will on a regular basis submit information to IMF staff with the frequency and submission time lag as indicated in Table 1. The information should be mailed electronically to AFRUGA746@IMF.ORG.

\footnotetext{
${ }^{5}$ This definition is consistent with the coverage of public sector borrowing defined by the Fund (includes the debt of the general government, monetary authorities, and entities that are public corporations which are subject to the control by government units, defined as the ability to determine general corporate policy or by at least 50 percent government ownership).
} 
Table 1. Summary of Reporting Requirements

\begin{tabular}{|c|c|c|c|}
\hline Reporting institution & Report/Table & Frequency & $\begin{array}{c}\text { Submission } \\
\text { lag }\end{array}$ \\
\hline \multirow[t]{10}{*}{ I. Bank of Uganda } & Issuance of government securities. & Weekly & $\begin{array}{l}5 \text { working } \\
\text { days }\end{array}$ \\
\hline & Interest rates on government securities. & Weekly & $\begin{array}{l}5 \text { working } \\
\text { days }\end{array}$ \\
\hline & $\begin{array}{l}\text { Operations in the foreign exchange market and daily } \\
\text { average exchange rates. }\end{array}$ & Weekly & $\begin{array}{l}5 \text { working } \\
\text { days }\end{array}$ \\
\hline & Consumer price index. & Monthly & 2 weeks \\
\hline & $\begin{array}{l}\text { Balance sheet of the BOU, consolidated accounts of the } \\
\text { commercial banks, and monetary survey. The Internal } \\
\text { Audit Department (IAD) of the BOU will review the } \\
\text { reconciliations of monetary survey data with the } \\
\text { financial records and the audited financial statements. } \\
\text { Any revisions to monetary survey data, in line with the } \\
\text { recommendations of the IMF safeguards mission, will } \\
\text { be documented and reconciled with the previous } \\
\text { presentation to ensure accurate reporting. }\end{array}$ & Monthly & 4 weeks \\
\hline & $\begin{array}{l}\text { Statement of (i) cash balances held in project accounts } \\
\text { at commercial banks; (ii) total value (measured at issue } \\
\text { price) of outstanding government securities from the } \\
\text { Central Depository System (CDS); and (iii) the stock of } \\
\text { government securities (measured at issue price) held by } \\
\text { commercial banks from the CDS. }\end{array}$ & Monthly & 6 weeks \\
\hline & $\begin{array}{l}\text { Summary of (i) monthly commodity and direction of } \\
\text { trade statistics; (ii) stock of external debt, } \\
\text { disbursements, principal and interest, flows of debt } \\
\text { rescheduling and debt cancellation, arrears, and } \\
\text { committed undisbursed balances-by creditor category; } \\
\text { and (iii) composition of nominal HIPC Initiative } \\
\text { assistance, disaggregated into grants, flow rescheduling, } \\
\text { and stock-of-debt reduction by creditor. }\end{array}$ & Monthly & 6 weeks \\
\hline & $\begin{array}{l}\text { Summary of external debt, external arrears, and } \\
\text { committed undisbursed loan balances by creditor. }\end{array}$ & Quarterly & 6 weeks \\
\hline & $\begin{array}{l}\text { Standard off-site bank supervision indicators for deposit } \\
\text { money banks. }\end{array}$ & Quarterly & 4 weeks \\
\hline & $\begin{array}{l}\text { Summary table of preliminary program performance } \\
\text { comparing actual monthly outcome with adjusted } \\
\text { program targets for (i) base money; (ii) net claims on } \\
\text { central government by the banking system; (iii) stock of } \\
\text { external arrears; (iv) new nonconcessional external } \\
\text { borrowing; and (v) net international reserves }\end{array}$ & Quarterly & 5 weeks \\
\hline
\end{tabular}


Table 1. Summary of Reporting Requirements

\begin{tabular}{|c|c|c|c|}
\hline Reporting institution & Report/Table & Frequency & $\begin{array}{l}\text { Submission } \\
\text { lag }\end{array}$ \\
\hline \multirow[t]{7}{*}{ II. Ministry of Finance } & $\begin{array}{l}\text { Summary of central government accounts. Revenues } \\
\text { shall be recorded on a cash basis. Expenditures shall be } \\
\text { recorded when checks are issued, except for domestic } \\
\text { and external debt-service payments, cash transfers to } \\
\text { districts, and externally funded development } \\
\text { expenditures. Expenditures on domestic interest will be } \\
\text { recorded on an accrual basis and external debt service } \\
\text { will be recorded on a commitment basis (i.e., when } \\
\text { payment is due). Cash transfers to districts will be } \\
\text { recorded as expenditures of the central government } \\
\text { when the transfer is effected by the BOU. Expenditures } \\
\text { on externally funded development programs will be } \\
\text { recorded as the sum of estimated disbursements of } \\
\text { project loans and grants by donors, less the change in } \\
\text { the stock of government project accounts held at the } \\
\text { BOU and domestic commercial banks. }\end{array}$ & Monthly & 6 weeks \\
\hline & $\begin{array}{l}\text { Summary of outstanding stock of group (B) domestic } \\
\text { arrears. Group (B) arrears comprise the stock of } \\
\text { CCS/IFMS arrears incurred after end-June } 2004 \text {. }\end{array}$ & Quarterly & 6 weeks \\
\hline & $\begin{array}{l}\text { Summary of contingent liabilities of the central } \\
\text { government. For the purpose of the program, contingent } \\
\text { liabilities include all borrowings by statutory bodies, } \\
\text { government guarantees, claims against the government } \\
\text { in court cases that are pending, or court awards that the } \\
\text { government has appealed. }\end{array}$ & Quarterly & 6 weeks \\
\hline & $\begin{array}{l}\text { Detailed central government account of disbursed } \\
\text { budget support grants and loans, HIPC support, and } \\
\text { external debt service due and paid. }\end{array}$ & Monthly & 4 weeks \\
\hline & $\begin{array}{l}\text { Detailed central government account of disbursed donor } \\
\text { project support grants and loans. }\end{array}$ & Monthly & 6 weeks \\
\hline & $\begin{array}{l}\text { Statement on new loans contracted during the period } \\
\text { according to loan agreements. }\end{array}$ & Quarterly & 6 weeks \\
\hline & $\begin{array}{l}\text { Updated national accounts statistics (real and nominal) } \\
\text { according to UBOS and medium-term projections. }\end{array}$ & Quarterly & 4 weeks \\
\hline
\end{tabular}




\title{
INTERNATIONAL MONETARY FUND
}

UGANDA

\section{First Review Under the Policy Support Instrument and Modifications to Assessment Criteria-Informational Annex}

\author{
Prepared by the African Department \\ (In consultation with other departments) \\ Approved by Robert Corker and Anthony R. Boote
}

May 31, 2007

- $\quad$ Relations with the Fund. Describes financial and technical assistance by the IMF and provides information on the safeguards assessment and exchange system. Outstanding Fund credit was SDR 6 million (3 percent of quota) at end-April 2007.

- $\quad$ Relations with the World Bank Group. Describes World Bank Group strategy, portfolio, and Bank-Fund collaboration.

- $\quad$ Statistical Issues. Assesses the quality of statistical data. Economic data are generally adequate for surveillance purposes, although some shortcomings remain. 


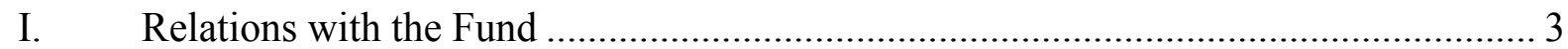

II. Relations with the World Bank Group........................................................... 8

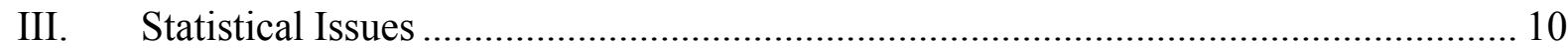




\section{APPENDIX I. UgANDA: RELATIONS WITH THE FUND}

(As of April 30, 2007)

I. Membership Status: Joined 09/27/1963; Article VIII

II. General Resources Account:

Quota

Fund holdings of currency

III. SDR Department:

Net cumulative allocation

Holdings

IV. Outstanding Purchases and

Loans:

Enhanced Structural Adjustment Facility

(ESAF)/Poverty Reduction and Growth

Facility (PRGF) arrangements

V. Financial Arrangements:

$\begin{array}{lcccc}\text { Type } & \begin{array}{c}\text { Approval } \\ \text { Date }\end{array} & \begin{array}{c}\text { Expiration } \\ \text { Date }\end{array} & \begin{array}{c}\text { Amount Approved } \\ \text { (SDR Million) }\end{array} & \begin{array}{c}\text { Amount Drawn } \\ \text { (SDR Million) }\end{array} \\ \text { PRGF } & 09 / 13 / 2002 & 01 / 31 / 2006 & 13.50 & 13.50 \\ \text { ESAF/PRGF } & 11 / 10 / 1997 & 03 / 31 / 2001 & 100.43 & 100.43 \\ \text { ESAF } & 09 / 06 / 1994 & 11 / 09 / 1997 & 120.51 & 120.51 \\ \text { ESAF } & 04 / 17 / 1989 & 06 / 30 / 1994 & 219.12 & 219.12\end{array}$

SDR Million

180.50

180.51

SDR Million

29.40

0.35

SDR Million

6.00

3.32

$\%$ Allocation

100.00

1.21

$\%$ Quota

100.0
100.0

VI. Projected Payments to Fund

(based on existing use of resources and present holdings of SDRs)

Overdue Forthcoming
Principal

$\underline{2007} \quad \underline{2008}$

0.00

$\frac{2009}{0.00}$

$\underline{\underline{0.95}} \quad \underline{\underline{0.95}} \quad \underline{1.26}$

1.26

$\underline{1.26}$

2010

0.20

$\underline{2011}$

1.00

Charges/interest

Total

$\underline{1.26}$

$\underline{1.26}$

$\underline{2.26}$

$\underline{0.95} \quad \underline{1.26}$


VII. Implementation of HIPC Initiative:

Commitment of HIPC assistance

\begin{tabular}{|c|c|}
\hline $\begin{array}{r}\text { Original } \\
\text { framework }\end{array}$ & $\begin{array}{r}\text { Enhanced } \\
\text { framework }\end{array}$ \\
\hline $4 / 23 / 1997$ & $2 / 7 / 2000$ \\
\hline 347.00 & 656.00 \\
\hline 68.90 & 91.00 \\
\hline
\end{tabular}

Decision point date

Assistance committed (1999 NPV terms) ${ }^{1}$

Total assistance (US\$ million)

Of which: Fund assistance

(US\$ million)

Completion point date

April 1998 May 2000

Delivery of Fund assistance (SDR million)

Assistance disbursed to the member

51.51

68.10

119.61

Interim assistance

8.20

Completion point balance

51.51

59.90

111.41

Additional disbursement of interest income ${ }^{2}$

2.06

2.06

VIII. Implementation of MDRI Assistance

I. Total Debt Relief (SDR Million) ${ }^{3}$

87.73

Of which: MDRI

75.85

HIPC

11.88

II. Debt Relief by Facility (SDR Million)

\section{Eligible Debt}

\section{Delivery}

Date

$\underline{\text { GRA }}$

PRGF

$\underline{\text { Total }}$

January 2006

$\mathrm{N} / \mathrm{A}$

87.73

87.73

\footnotetext{
${ }^{1}$ Net present value (NPV) terms at the completion point under the original framework, and NPV terms at the decision point under the enhanced framework.

${ }^{2}$ Under the enhanced Initiative for Heavily Indebted Poor Countries (HIPC Initiative), an additional disbursement is made at the completion point corresponding to interest income earned on the amount committed at the decision point but not disbursed during the interim period.

${ }^{3}$ The Multilateral Debt Relief Initiative (MDRI) provides 100 percent debt relief to eligible member countries that are qualified for the assistance. The debt relief covers the full stock of debt owed to the Fund as of end-2004 which remains outstanding at the time the member qualifies for such debt relief. The MDRI is financed by bilateral contributions and the Fund's own resources, as well as the resources already disbursed to the member under the HIPC Initiative (see Section VII above).
} 


\section{Safeguards Assessments}

Under the Fund's safeguards policy, assessments with respect to the PSI are voluntary. An update assessment of the Bank of Uganda (BOU) was completed on April 10, 2007 and concluded that the BOU had strengthened its safeguards framework since the 2003 assessment. The main developments included implementation of International Financial Reporting Standards, publication of financial statements, establishment of an audit committee, and strengthening of the internal audit function. Staff made recommendations to address remaining vulnerabilities in the legal and internal control areas.

\section{Exchange Rate Arrangement}

The official exchange rate is determined on the interbank market for foreign exchange. As of April 30, 2007, the official exchange rate was U Sh 1,726.7 per U.S. dollar. The exchange system is free of restrictions on the making of payments and transfers for current international transactions. Uganda is classified as an independently floating exchange rate regime.

\section{Article IV Consultation}

The Executive Board concluded the last Article IV consultation on December 15, 2006. The next Article IV consultation with Uganda will be held on the 24-month cycle, subject to the provisions of the decision on consultation cycles approved on July 15, 2002.

In February and April 2001, joint World Bank/Fund missions visited Kampala as part of the Financial Sector Assessment Program (FSAP). A final report was provided to the authorities in November 2001, and an MFD mission discussed the report with the authorities during the Article IV consultation discussion in November 2002, and the Financial System Stability Assessment was prepared for Board discussion in February 2003. In November 2004, a joint World Bank/Fund missions visited Kampala for a FSAP update.

\section{Policy Support Instrument (PSI)}

Uganda initiated a 16-month PSI with the Fund in January 2006. The 16-month PSI was replaced by a new three-year PSI in December 2006.

\section{Technical Assistance}

Uganda has received extensive technical assistance from the Fund in recent years. ${ }^{4}$

An FAD mission visited Kampala in April 1998 to advise the authorities on public service pension reform issues, and another mission visited Kampala in September 1998 to assist the authorities in improving customs administration procedures. A resident advisor in the area of local government budgeting began a six-month assignment in August 1998, which was

\footnotetext{
${ }^{4}$ For a description of technical assistance provided prior to 1998, see the staff report for Uganda's request for a three-year arrangement under the PRGF (Country Report 02/213).
} 
subsequently extended to October 1999. An FAD resident advisor on budgeting and commitment control commenced a six-month assignment in November 1998, which was extended until June 2002. In October 2000, an FAD mission visited Kampala to provide technical assistance in tax policy and administration. A joint Bank/Fund TA mission visited Kampala in October 2003 to help harmonize tax investment incentives among the member countries of the EAC. An FAD TA mission on tax administration also visited Uganda in October 2004 to develop a comprehensive reform plan for the Uganda Revenue Authority (URA), followed by visits in April 2005 and April - May 2006. Two FAD resident advisors (coordinated through AFRITAC-East) are currently in the field assisting the implementation of a CCS at the local government level and the Fiscal Decentralization Strategy.

A STA multisector statistics mission visited Kampala in December 1998 to conduct a comprehensive assessment of Uganda's macroeconomic statistics, including data compilation and dissemination, and to provide recommendations for improvements. Follow-up STA missions in national accounts and money and banking statistics visited Kampala in MarchApril 2000 to examine the status of implementation of the previous recommendations. A STA mission on government financial statistics (GFS) visited Uganda in December 2001 to assist authorities in improving fiscal reporting by establishing regular reporting systems that are aligned with the GFS Manual 2001, as well as ensuring consistency within monetary sector data for the government. A follow-up mission on GFS visited Uganda in May 2003. A mission visited Uganda during February-March 2002 to review balance of payment statistics and the progress in implementing the recommendations of the multisector mission of 1998 and of the national accounts mission of 2000 with respect to the measurement of goods imports. A follow-up mission on balance of payments statistics visited Uganda in August 2003. Uganda is participating in the General Data Dissemination System (GDDS) and its metadata were initially posted on the Fund's Dissemination Standards Bulletin Board in May 2000. A STA mission was in Uganda during February 2005 to prepare a data ROSC.

Since the 2001 FSAP, MFD's TA to Uganda has focused on liquidity management, exchange rate intervention, central bank accounting and auditing, and banking supervision. The authorities have effectively used TA advice on these topics, and they have made good use of an MFD resident advisor, who took up her initial appointment in mid-July 2001. The advisor was fully integrated into the supervision function and has been involved in all aspects of the work, including participating in on-site examinations; she has subsequently been replaced by a second resident advisor. MFD has fielded two TA missions (July 2001 and January 2002) to assist the authorities with liquidity management and address the problems of interest rate volatility and exchange rate interventions. The BOU has started implementing the recommendations made in the report, and now clearly separates sterilization operations and liquidity management; however, they are still having problems with interest rate and exchange rate volatility and have requested follow-up TA in this area. In March and SeptemberOctober 2002, MFD provided TA to improve central bank accounting and the Bank of Uganda's accounting manual. A TA evaluation visit was conducted in June 2003, and an MFD mission following up on monetary and exchange rate operations, public debt, and liquidity management was conducted in March 2004. An FSAP update mission was conducted in November 2004 and focused on access, outreach, and stability issues, which also updated progress made since the last FSAP. A TA mission on enhancing the effectiveness of monetary policy implementation and developing financial markets was conducted in August 2005. Finally, a joint MCM/BOU workshop on financial market development was held in April 2006. 


\section{Future Technical Assistance Priorities}

The priorities for Fund technical assistance in the next few years will be in the areas of tax administration, public expenditure management, especially control and monitoring of public arrears at both central and local government levels, monetary and exchange rate management, bank supervision, national accounts statistics, reporting standards for government finance statistics, monetary and balance of payments statistical reporting, central bank accounting, and audit and debt management.

\section{Resident Representative}

The Fund has maintained a resident representative in Uganda since July 1982. 


\section{APPENDIX II. UGANDA: RELATIONS WITH THE WORLD BANK GROUP}

(As of April 23, 2007)

\section{Partnership in Uganda's Development Strategy}

1. Uganda's development strategy is based on the revised Poverty Eradication Action Plan (PEAP) $)^{5}$ launched in May 2005. This medium-term national planning framework guides government policy both at sector and district levels. The PEAP aims at accelerating economic growth, reducing poverty and inequality, and improving human development. It has five pillars: (i) economic management; (ii) production, competitiveness and income; (iii) security, conflict-resolution, and disaster management; (iv) good governance; and (v) human development.

\section{Bank Group Strategy}

2. The World Bank's assistance to Uganda is set out in a Joint Assistance Strategy (UJAS) which was approved by the Bank's Board in January 2006. The strategy now guides the activities of 10 other development partners in addition to the Bank. Within it, the Bank provides substantial support to the PEAP through annual Poverty Reduction Support Credits (PRSCs). PRSC6 was presented to the World Bank's Executive Board in April 2007.

3. Another form of direct budget support is debt relief. In addition to the Heavily Indebted Poor Countries (HIPC) initiatives ${ }^{6}$, Uganda receives 100 percent debt relief under the Multilateral Debt Relief Initiative (MDRI) approved by the World Bank Board on March 28, 2006. The initiative, which became effective July 01, 2006, will cancel US\$2.7 billion of Uganda's IDA debt.

\section{Bank Portfolio}

4. As of March 31, 2007, Uganda's portfolio included 18 Bank-supported projects, with total net commitments of US\$1,013 million. US\$536 million of this amount was not yet disbursed.

5. For the fiscal year 2006/07, projects in the pipeline (Board date April 26, 2007) include PRSC6 (US\$125 million), Power Sector Development project (US\$300 million), and the Private Power Generation (Bujagali) project (US\$115 million). In fiscal year 2005/06, PRSC5(US\$135 million), Public Service Enhancement Program (US\$70 million), the East African Trade and Transport facilitation project (US\$27 million), Millennium Science Initiative Project (US\$10 million) were approved by the Board.

\footnotetext{
${ }^{5}$ The PEAP, first prepared in 1997 is a dynamic document and was revised in 2000 and 2004.

${ }^{6}$ Uganda reached completion point for the HIPC in April 1998 and for the Enhanced HIPC in May 2000.
} 


\section{Bank-Fund Collaboration in Specific Areas}

6. Specific areas for collaboration include:

- Poverty reduction strategy paper - The staffs of the two institutions prepare joint assessments of the PRSP and progress reports.

- Debt sustainability analysis - The Uganda DSA, last updated in November 2006, will be updated during 2007/08.

- Public expenditure management - Through the 2005 public expenditure review (PER), the World Bank helped to prepare an action plan for public expenditure and financial accountability which is monitored annually by a Government-chaired working group. The Bank's public expenditure reviews have now moved "upstream" to consider fiscal space, the strategic allocation of resources across sectors, and the efficiency of sector spending. The education sector will feature in this year's PER.

- Financial sector reform - The Bank and Fund completed a Financial Sector Assessment Program update in March 2005. In addition under the Country Economic Memorandum, the Bank carried out a thorough assessment of priorities to facilitate growth and deepening in Uganda's financial sector. Capacity-building work to support implementation on this work is closely coordinated with the Fund's PSI.

- Trade reforms - Both the Bank and Fund are involved in the dialogue on trade reforms in the context of the East African Community (EAC). In 2006, the Bank completed a diagnostic trade integrated study.

Questions may be referred to Dino Merotto, Country Economist, Tel. (202) 458-1987. 


\section{APPENDIX III. UGANDA: STATISTICAL ISSUES}

Overall, data provision is adequate for surveillance purposes, although some shortcomings remain. Uganda participates in the General Data Dissemination System (GDDS) and its metadata were initially posted on the Fund's Dissemination Standards Bulletin Board in May 2000. Partial updates of real and external sector metadata were completed in August 2005.

In February 2005 a STA mission prepared a data ROSC, with results were published in July 2006. The ROSC mission assessed data compilation and dissemination practices against international standards in national accounts, prices, government finance, and balance of payments statistics; the monetary and financial statistics were not assessed. In April 2007 a mission conducted a Special Data Dissemination Standards (SDDS) assessment focusing on dissemination practices vis-à-vis the SDDS requirements for coverage, periodicity and timeliness.

\section{Real sector statistics}

Since 2004 Uganda has been receiving technical assistance from East AFRITAC on the compilation of quarterly national accounts and training through short missions and a regional workshop. Recently, compilers have developed estimates of quarterly value added at constant 2002 prices using the International Standard Industrial Classification (ISIC) Rev III groups. However, methodological shortcomings remain relating to benchmarking. The Uganda Bureau of Statistics (UBOS) collects output data from a sample of manufacturing business establishments in the industrial belt of the country to compile a Major and a Main Index of Industrial Production (IIP). Labor market indicators such as employment, unemployment, and wages/earnings are infrequently compiled and disseminated. UBOS aims to compile and disseminate these data categories on an annual basis, but due to resource and data unavailability, these data are compiled with a two year lag. UBOS collects prices of consumer goods and services from six urban centers for computing inflation rates disseminated on the last working day of every month. According to UBOS, there are plans to expand the coverage to include another urban center. UBOS collects producer prices (factory gate prices) from a sample of manufacturing establishments located in different parts of the country, which undertake manufacturing activities as classified by ISIC. The price information is used to compute the Producer Price Index for Manufacturing (PPI-M).

\section{Government finance statistics}

The Ministry of Finance, Planning and Economic Development (MoFPED) compiles the fiscal statistics on general government including budgetary central government and local governments but excluding extra budgetary institutions. A revised chart of accounts was implemented for use by all budgetary central government and local government units from July 1, 2003. Uganda commenced reporting Government Finance Statistics (GFS) data according to the GFSM 2001 framework for the 2004 GFS Yearbook. However, data 
coverage is limited to the budgetary central government and local government accounts, and excludes the activities of extrabudgetary central government units and the National Social Security Fund. External debt for the public sector, external debt guaranteed by the public sector, and debt service schedule data are disseminated in millions of dollars and in Uganda shillings (using end of year exchange rates) for the fiscal year (July to June).

\section{Monetary and financial statistics}

The monetary survey data cover the Bank of Uganda (BOU) and 18 commercial banks, three of which are under liquidation. The operating banks consist of 12 foreign owned banks and three domestic banks. The data are compiled from the analytical accounts of the BOU, and data provided by commercial banks are from a reporting format (BS100) based on the Standardized Reporting Forms. The monetary survey does not cover the balances of four credit institutions and four microfinance institutions that accept deposits, and are regulated by BOU. However, data from these institutions are collected on a monthly basis, and included in the Quarterly and Annual Economic reports, as well as the Monthly Economic Review. The BOU intends to compile data from other financial institutions such as insurance corporations and pensions funds, and to include them in a financial corporation's survey by June 2009.

Base (reserve) money, defined as currency outside the BOU and commercial bank deposits with the BOU, are compiled on a daily basis by the BOU. Data are derived from accounting records of the Central Bank. Detailed data on base money, and other liabilities, as well as domestic and net foreign assets are compiled and disseminated on a monthly basis. The central bank's survey does not yet meet the SDDS timeliness requirement.

In February 2006, a monetary and financial statistics mission found that the monetary statistics are basically sound from the point of view of data integrity and timeliness. However, there are a number of areas where improvements are needed to align the data with the recommendations of the Monetary and Financial Statistics Manual (MFSM). The detailed balance sheet of the Bank of Uganda is well designed for producing the analytical data; however, (1) reverse repos between the BOU and commercial banks are not classified as advances to banks, (2) there is some inconsistency among departments in the BOU in determining which foreign assets are in reserve assets; (3) loans and advances are presented net of provisions for loans losses; (4) the proper classification of many positions of the Development Finance Department is difficult because the main classification used in the accounts is the original source of funds, rather than the unit subject to a claim or liability; and (5) the economic and accounting nature of administered and internally managed funds of the BOU is unclear.

The principal issue with regard to the quality of the data of other depository corporations (ODCs) is the exclusion of two classes of depository corporations from the monetary survey. At present, the monetary survey covers the balances of the BOU and the commercial banks only. However, there are also seven credit institutions and four microfinance institutions that accept deposits. The 2006 mission, therefore, recommended that the depository corporations 
sector be defined to include these deposit-taking corporations, and that their deposits be included in the monetary aggregates.

\section{External sector statistics}

The ROSC mission found that the balance of payments statistics broadly follow the fifth edition of the Balance of Payments Manual (BPM5), but that there are some departures from recommended definitions, scope, and classifications. The mission urged completion of the conversion to the BPM5 and the development of new source data and estimation techniques in the following areas: exports of freight and imports of passenger transportation, compensation of employees, direct investment abroad, portfolio investment and financial derivatives. International trade data could be improved by incorporation of results from the Survey of Informal Cross-Border Trade and greater use of trade partner country data sources.

Balance of payments data are compiled and disseminated for calendar and fiscal years in the BOU's publications Quarterly Economic Report and Annual Report, as well as the UBOS annual Statistical Abstract. Data cover the entire economy and include all operations between residents and nonresidents. Quarterly balance of payments data are disseminated in an analytical format or on the basis of standard components, in accordance with the requirements of the IMF Balance of Payments Manual, Fifth Edition (BPM5).

The BOU have requested technical assistance to determine better ways in which trade data can be compiled. The BOU is also seeking technical assistance to determine how best to capture securities trading and deposits from off-shore agents into the balance of payments. 


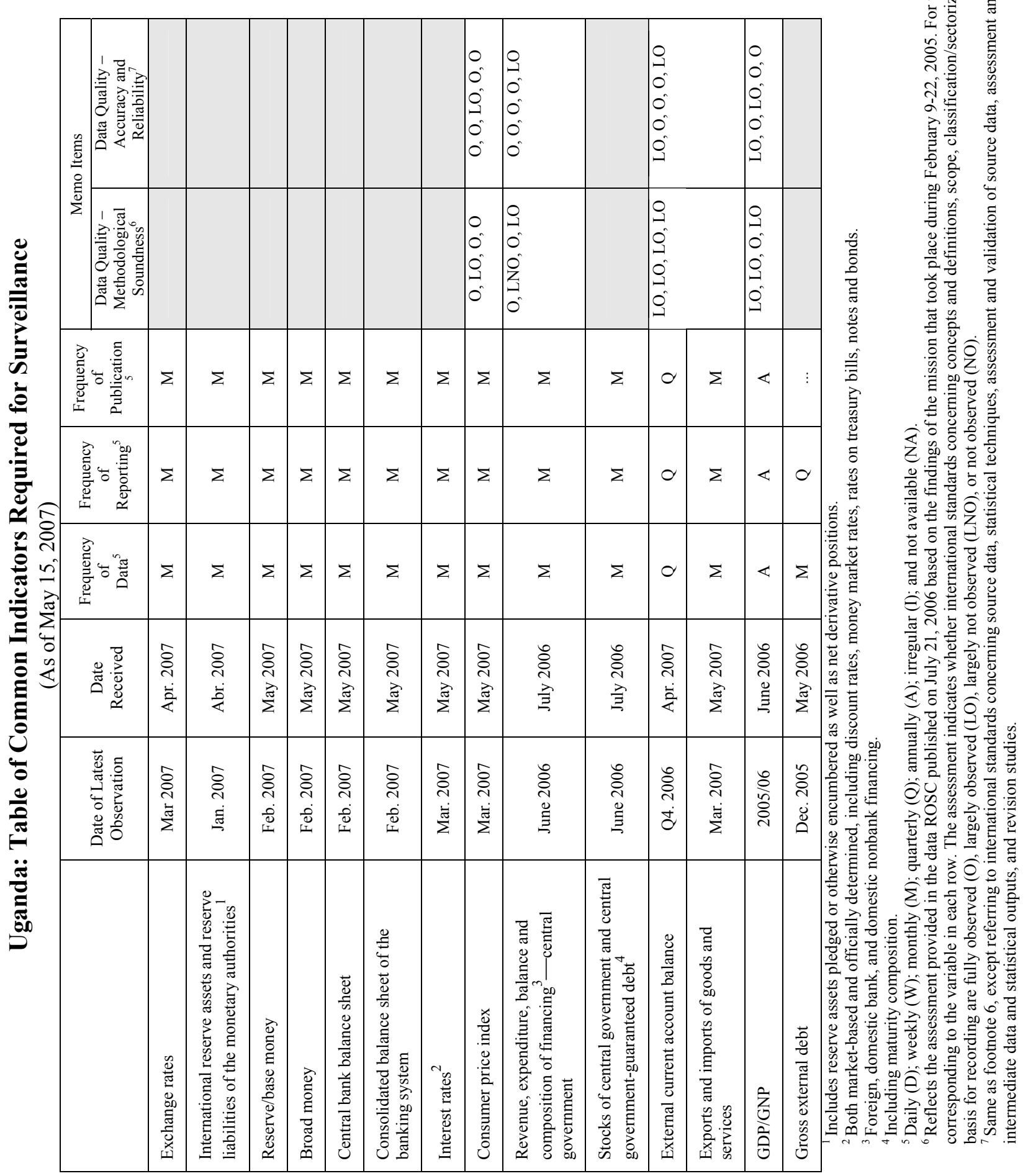


Press Release No. 07/133

International Monetary Fund

FOR IMMEDIATE RELEASE

Washington, D.C. 20431 USA

June 15, 2007

\section{IMF Executive Board Completes the First Review under the Policy Support Instrument for Uganda}

The Executive Board of the International Monetary Fund (IMF) today completed the first review under the three-year Policy Support Instrument (PSI) for Uganda. The PSI was approved on December 15, 2006 (see Press Release No. 06/281). The program objectives included macroeconomic stability, debt sustainability, financial sector deepening, and improved public sector financial management.

The IMF's framework for PSIs is designed for low-income countries that may not need IMF financial assistance, but still seek close cooperation with the IMF in preparation and endorsement of their policy frameworks. PSI-supported programs are based on countryowned poverty reduction strategies adopted in a participatory process involving civil society and development partners. This is intended to ensure that PSI-supported programs are consistent with a comprehensive framework for macroeconomic, structural and social policies to foster growth and reduce poverty. Members' performance under a PSI is reviewed semi-annually, irrespective of the status of the program (see Public Information Notice No. $\underline{05 / 145)}$.

Following the Executive Board discussion, Mr. Takatoshi Kato, Deputy Managing Director and Acting Chair, made the following statement:

“Uganda's economic performance has been strong, and poverty indicators are improving. The authorities remain committed to the program, as demonstrated by their prudent fiscal and monetary policies and determined effort on the structural front. The economic outlook continues to be positive.

"Prudent control over current nonpriority spending and strengthening of tax administration will be essential to achieve the government's goal of increasing public savings. It will be important to limit wasteful spending and supplementary budget reallocations in nonpriority areas, and to continue modernization of the Uganda Revenue Authority. Caution in 
introducing tax incentives to attract investment is warranted, given the budgetary impact and distortionary effects.

"The budget appropriately sets aside increased resources to repay domestic arrears. Success in preventing new arrears will require full funding of statutory obligations and a commitment to budget principles at all levels of government. The government's plan to strengthen public expenditure management will also be important.

"The authorities are committed to maintaining debt sustainability, following substantial debt relief. The new debt management strategy is an important step in this direction and should be faithfully implemented.

"A series of temporary shocks has led to a spike in inflation. While monetary tightening is not necessary at this stage, the central bank needs to watch carefully for signs of underlying price pressures.

"Uganda's competitiveness and ability to diversify its exports depend crucially on investment in education and infrastructure, financial sector development, and enhancements to the business environment. Current efforts to resolve the electricity crisis are particularly welcome, while continued action to improve governance will be crucial to attract private investment and unlock additional donor assistance," Mr. Kato said. 


\section{Statement by Peter Gakunu, Executive Director for Uganda and Godwill Efiong Ukpong, Senior Advisor to the Executive Director June 15, 2007}

1. The Ugandan authorities are appreciative of the Fund's continuous engagement and support for their ambitious macroeconomic and structural reform efforts under the PSI. They note the report which they consider to be balanced and informative on the country's economic achievements, challenges and prospects. They broadly agree with the thrust of the analyses, conclusions, and recommendations in the report.

\section{Recent Macroeconomic Developments and Performance}

2. Disciplined fiscal performance, prudent monetary policy implementation, and strong effort on carrying out structural reforms have underlied the achievement of economic objectives and progress in meeting other set criteria and targets. These include: real GDP growth of about 6.2 percent in 2006/07 even as drought-related electricity supply problem has a dampening effect on general economic activity; and subdued average headline inflation of 5.8 percent in 2006/07, relative to 6.6 percent in 2005/06, with recent spike in inflationary pressure explained largely by a sharp increase in electricity tariffs and temporary diesel fuel and sugar shortages. In addition, the Joint Staff Advisory Note and recent National Household Survey indicate that the relatively robust economic growth and higher coffee prices, especially in the last three years, have benefited many Ugandans and contributed to both the fall in the incidence of poverty and income inequality.

3. A fully-funded supplementary budget in 2006/07 has provided additional funding in several areas, including parliament, and a temporary bridge loan for commencement of construction of the Bujagali dam, partly guaranteed by the World Bank, and for which financing arrangements are to be finalized around July 2007. The monetary authority has maintained a tight monetary policy stance which has helped contain inflation, curtail excess liquidity in the system and create a suitable environment for banks to lend to the private sector.

4. Notwithstanding the significant achievements highlighted, the Ugandan authorities recognize that the economy still faces a number of important challenges, including the need to achieve sustainable higher rates of real GDP growth for further substantial poverty reduction; keeping inflation continuously in check; continuing with fiscal consolidation to progressively reduce dependence on donor funds; and maintaining debt sustainability. Besides, there is also the need to minimize identified risks to the economic outlook, namely, improving electricity supply and providing for other essential human and physical infrastructure to stimulate private sector investment and growth. Fortunately, the authorities, in line with their track record of good economic management, are already adopting suitable measures to address the various challenges. In this regard, a debt management and sustainability strategy has been developed; the Bank of Uganda (BOU) continues to study and monitor developments in exchange rate to ensure its stability; while the supply of credit 
to the private sector is considered significant to stimulate investment and growth. The electricity crisis, the most pressing short-term challenge, is being addressed, and macroeconomic policies continue to be well-formulated and implemented.

\section{Performance Under the PSI}

5. The authorities' strong commitment to successful implementation of macroeconomic and structural policies, as set out in the PSI, has resulted in their meeting all assessment criteria through end- May 2007 (Tables 6 and 7). Domestic arrears repayment is on track to meet the 2006/07 budget allocation of 0.75 percent of GDP. An indicative target on poverty alleviation, missed by a small margin, was related to lags in expenditure processing. The government's negative borrowing requirement and the robust economy have been conducive to the development of the financial sector, with interest rates on treasury bills remaining broadly stable, and credit to the private sector growing strongly. A pick-up in foreign exchange inflows, including portfolio inflows, has put pressure on the dollar-shilling exchange rate. In order to avoid instability in the forex market, the BOU is relying more on open market operations to sterilize the inflows.

\section{Macroeconomic Policies for 2007/08 and the MTEF}

6. Uganda's economic policies are aimed at reducing poverty by maintaining macro stability and addressing constraints to growth, especially infrastructure deficit. In this regard, and as set out in the Poverty Eradication Action Plan (PEAP), the MTEF and the PSI, the authorities are adhering to their commitment of continuing with fiscal consolidation; maintaining low inflation; minimizing exchange rate pressures; investing in health, education and physical infrastructure; and supporting private sector growth through implementation of second generation reforms. Against this background, strong economic performance is expected to continue. Real GDP growth of over 6 percent is projected for the coming years, while underlying inflation is to be reduced to 4 percent by end-2007/08. While domestic debt is expected to decline, the trade balance is projected to deteriorate owing to imports for the Bujagali dam project, which is expected to eventually improve electricity supply. However, energy imports by Uganda could be lowered by US \$150 million a year and the electricity crisis alleviated further if the country's test oil wells, which show limited but commercially viable production, could come on stream by 2009.

7. The staff consider the medium-term economic outlook as positive, while the main risks to the outlook are electricity and infrastructure bottlenecks. It is assumed that delays in construction of the Bujagali dam would impose substantial costs on government and businesses at a time that a need exists to provide better and more extensive transport networks critical for sustainable economic growth. The authorities are, however, taking necessary measures to successfully manage these risks, including intensification of efforts to conclude funding guarantee with the World Bank and to mobilize more resources internally through improved tax collection and public expenditure management, to finance construction of the dam. 


\section{Fiscal Policy and Public Sector Reforms}

8. The 2007/08 budget is underpinned by the government's strategy of increasing public savings through expenditure restraint and improved revenue collection. The authorities plan to increase revenue to GDP ratio by 0.5 percentage points through continuous reform of the Uganda Revenue Authority (URA), including further computerization, improved taxpayer registration, and more frequent audits of tax compliance. The priority areas identified to receive attention under the budget are rural development for poverty reduction; education to enhance human capacity building; and infrastructure to induce growth. The government is also to continue seeking for higher efficiency in service delivery and exploring pay reforms. The authorities have noted the staff's recommendation and advice to minimize the budget impact of planned introduction of tax incentives to encourage foreign investment and exports in line with the policy of neighboring countries. They will bear this in mind before taking a decision.

9. The authorities have prepared a comprehensive Debt Management Strategy to support their fiscal priorities. The strategy outlines the principles for external and domestic borrowing, including only on concessional terms, budget support, and essential infrastructure projects. It also sets out the modality for repaying old domestic arrears in the next three years, and formulation of policies to address the underlying causes of accumulation of new arrears. The government's plan to guarantee US\$ 5.5 million non-concessional loan from a Japanese bank to a local textile company on a transaction dating back to 2003, is an exception.

\section{Monetary and Financial Sector Policies}

10. The authorities are committed to pursuing a monetary program that would continue to target base money and aim at bringing underlying inflation to low single digits by end-2007/08. The BOU is adopting a mix of instruments that would help achieve the inflation objective, while taking into account the volume and nature of capital inflows and their likely effect on the exchange rate. It is also relying mostly on sales of government securities for the purpose of mopping up excess liquidity and is monitoring the recent shilling appreciation. The BOU is also tightening reporting requirements on Treasury bill ownership and studying invisible flows in the balance of payments.

\section{Other Structural Reforms}

11. The government is tackling the issue of governance and is taking necessary action on a few cases of inappropriate conduct, such as misappropriation of donor funds at the Ministry of Health. The authorities are aware of the value of regional cooperation in the provision of incentives, such as tax concessions, to enhance competition and attract investment. Such an approach would assist them to avoid or minimize the risk of tax revenue losses. 


\section{Conclusion}

12. The Ugandan authorities have continued to demonstrate strong commitment to effective implementation of sound macroeconomic and structural reform policies to improve economic management, accelerate sustainable real GDP growth for poverty reduction, and reinforce their efforts towards attainment of the MDGs. They have met all end-May 2007 assessment criteria under the PSI. The government's budget strategy continues to aim at expenditure restraint and improved revenue collection in line with the MTEF for enhanced investment in rural development, education, and infrastructure. In line with the need to exercise caution in contracting loans, avoiding accumulation of unsustainable debt, and maintaining debt sustainability, the authorities have developed a Debt Management Strategy to guide the country's domestic and external borrowing. The authorities have remained committed to sustaining implementation of the country's economic reform program under the PSI. They call on the international community, including the Fund, to continue to support the country in the effort to overcome the remaining challenges to economic progress and development. They, therefore request approval for completion of the review of performance under the PSI. 